\title{
Global trends in coronavirus research at the time of Covid-19: A general bibliometric approach and content analysis using SciMAT
}

\author{
Enrique Herrera-Viedma; José-Ricardo López-Robles; Javier Guallar; \\ Manuel-Jesús Cobo
}

How to cite this article:

Herrera-Viedma, Enrique; López-Robles, José-Ricardo; Guallar, Javier; Cobo, Manuel-Jesús (2020). “Global trends in coronavirus research at the time of Covid-19: A general bibliometric approach and content analysis using SciMAT". El profesional de la información, v. 29, n. 3, e290322.

https://doi.org/10.3145/epi.2020.may.22

Manuscript received on May $11^{\text {th }} 2020$ Accepted on May 27th 2020

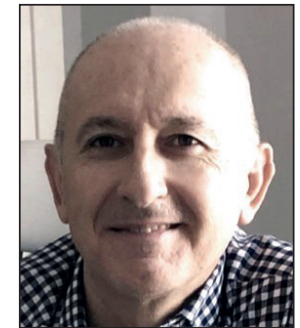

Enrique Herrera-Viedma http://orcid.org/0000-0002-7922-4984

University of Granada Department of Computer Science and Artificial Intelligence Av. del Hospicio, s/n. 18010 Granada, Spain viedma@decsai.ugr.es

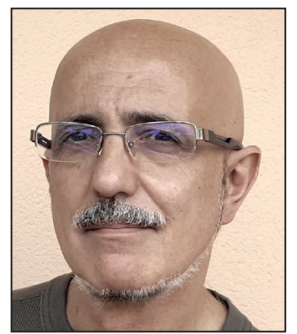

Javier Guallar http://orcid.org/0000-0002-8601-3990

University of Barcelona. Department of Information Science and Media Studies. CRICC Research Center Melcior de Palau, 140. 08014 Barcelona, Spain jguallar@ub.edu

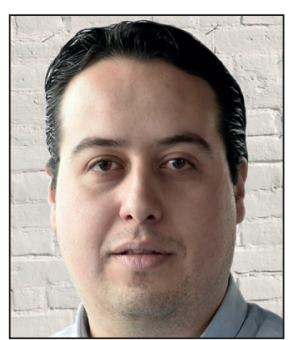

José-Ricardo López-Robles $\square$ http://orcid.org/0000-0003-3780-1955

Autonomous University of Zacatecas Post. Program of Eng. and Applied Tech. National Laboratory CONACYT-SEDEAM Av. Ramón López Velarde, Col. Centro 98000 , Zacatecas, México ricardolopezrobles@outlook.com

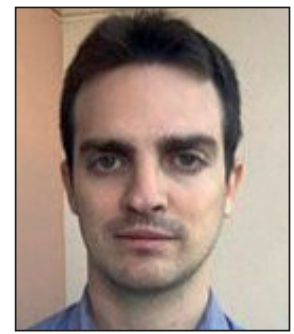

Manuel-Jesús Cobo http://orcid.org/0000-0001-6575-803X

University of Cádiz

Department of Computer Science and Engineering

Av. de la Universidad, 10.

11519 Puerto Real (Cádiz), Spain manueljesus.cobo@uca.es

\begin{abstract}
Covid-19 represents the greatest challenge facing mankind today. In December 2019, several cases of pneumonia of unknown etiology were reported from China. This coronavirus infection subsequently identified as Covid-19 aroused worldwide concern. As a result, the scientific community has focused attention on Covid-19, as revealed by recent research reported in literature based on a holistic approach. In this regard, this study conducts a bibliometric analysis of coronavirus research in the literature with an emphasis on Covid-19 disease, using as a reference the publications in the Web of Science Core Collection from 1970 to 2020. This research analyzes 12,571 publications from 1970 to (April 18) 2020 by applying advanced bibliometric techniques in SciMAT bibliometric analysis software. The current research therefore provides a complete conceptual analysis of the main coronavirus types and strains in the literature by quantifying the main bibliometric performance indicators, identifying the main authors, organizations, countries, sources, and research areas, and evaluating the development of this field. Furthermore, a science map is constructed to understand
\end{abstract}

Funding

This study has been carried out with support from the "Culture and Digital Content" consolidated research group (SGR 2017-422), funded by the Agency for the Management of University and Research Grants (Agaur) of the Generalitat de Catalunya. Additionally, the authors want to thank the Feder funds (TIN2016-75850-R), Mexican Consejo Nacional de Ciencia y Tecnología (Conacyt), and Mexican Dirección General de Relaciones Internacionales $(D G R I)$ for support. 
the corresponding intellectual structure and main research lines (themes). SciMAT thereby offers a complete approach to the field and evaluates the main performance indicators related to coronavirus, with a focus on Covid-19. Finally, this research serves as a framework to strengthen existing research lines and develop new ones, establishing synergistic relationships that were not visible without the maps generated herein.

\section{Keywords}

Covid-19; Coronavirus; Pandemics; Virus diseases; Novel coronavirus; Co-word analysis; Strategic intelligence; Mapping analysis; Bibliometric analysis; SciMAT.

\section{Introduction}

In January 2020, the World Health Organization (WHO) declared the coronavirus 2019-nCoV disease outbreak to be a public health emergency of international concern. On March 11, following an ongoing assessment of the outbreak and the alarming levels of its spread and severity, as well as inaction, the WHO declared the Covid-19 disease produced by the new coronavirus to be a pandemic (WHO, 2020).

In light of this situation, scientific production on this subject has exhibited strong growth in multiple disciplines. The health crisis caused by Covid-19 has triggered a reaction from the scientific community in the search for solutions to it, leading to an exponential growth in such literature (Torres-Salinas, 2020).

The multidisciplinary nature of the research carried out can be seen in the variety of fields involved, ranging from medicine to social sciences, including computer science and information technologies for the detection of behavior, genetic markers, and evolutionary patterns. Research has also been carried out to analyze the implications that geolocalization may have in relation to the privacy of individuals, as well as specific thematic analyses of social networks (Casero-RipoIlés, 2020; Lázaro-Rodríguez; Herrera-Viedma, 2020; Pérez-Dasilva; Meso-Ayerdi; Mendiguren-Galdospín; 2020; Rodríguez-Morales et al., 2020; Sahin et al., 2020; Thelwall; Thelwall, 2020).

Scientific journals represent one of the main sources of research, projects, and added-value information, providing a new reference point to conduct novel research into Covid-19.

Complete bibliometric analysis thus becomes a key tool to evaluate ongoing actions and research, organizations, countries, sources, and researchers (Bonilla-Aldana et al., 2020; Hossain, 2020). In this context, the main aim of this paper is to present a bibliometric analysis of coronavirus research with an emphasis on Covid-19 disease, covering authorship, production, and thematic analysis, with the distinction of covering the main and secondary research themes related to coronavirus types and strains, from the first publication in 1970 to the present day.

Thus, the present research focuses on an analysis and description of the development of the research themes about coronavirus and the main related concepts available in the literature using bibliometric techniques and tools. First, the research quantifies the main performance-related indicators: published documents, received citations, journal impact factor (JIF), h-index, most cited articles, most cited authors, and data on the geographic distribution of publications, among others. Next, SciMAT is used as a science mapping software tool to analyze the areas of development of scientific knowledge associated with the coronavirus types and strains within a defined time span (Cobo et al., 2012; López-Robles et al., 2020).

\section{Methodology and dataset}

Bibliometric techniques and methods represent some of the most common and widely accepted techniques to analyze the output of basic and advanced research. Such methods are increasingly valued as tools for measuring scientific quality, productivity, and evolution (Garfield; Merton, 1979; Hirsch, 2005; Martínez et al., 2015; Moed et al., 1995; Moed, 2009).

\subsection{Methodology}

In the current research, the bibliometric methodology is combined with performance analysis and science mapping approaches (Cobo et al., 2011). Moreover, this methodology can be employed to analyze a field of research, as well as to detect and visualize its conceptual subdomains (particular themes or general thematic areas), along with its thematic evolution. This approach is based on co-word analysis and the h-index (Callon et al., 1983; Garfield, 1986; Hirsch, 2005).

Although various software tools for science mapping analysis exist (Moral-Muñoz et al., 2020), SciMAT was applied in the current research due to its deduplication process and visualization based on strategic diagrams and thematic areas. The bibliometric methodology used here identifies four phases of analysis within a specified set of periods (Cobo et al., 2011; López-Robles et al., 2019a; López-Robles et al., 2019b):

- Detection of research themes. For each of the periods analyzed, research themes are detected by applying a clustering algorithm (Coulter et al., 1998) over a normalized co-word network (Callon et al., 1983).

- Visualizing research themes and the thematic network. The detected research themes are classified based on their 
centrality and density rank values into a strategic diagram (Callon et al., 1991; He, 1999). The centrality (c) measures the degree of interaction of a network with other networks, while the density (d) measures the internal strength of the network. By considering both types of measure, a field of research can be visualized as a set of research themes and plotted on a two-dimensional strategic diagram (Fig. 1 (a)). Thereby, the themes can be classified into four categories (Cobo et al., 2011):

a. Motor themes (quadrant Q1): The themes within this quadrant are relevant for developing and structuring the research field. They are known as the motor themes of the field, given that they present strong centrality and high density.

b. Highly developed and isolated themes (quadrant Q2): These are strongly related, highly specialized, and peripheral, but they do not have the appropriate background or importance for the field.

c. Emerging or declining themes (quadrant Q3): These themes are relatively weak and exhibit low density and centrality. They mainly represent either emerging or disappearing themes.

d. Basic and transversal themes (quadrant Q4): These themes are relevant for the field of research but are not well developed. This quadrant contains transverse and general basic themes.

- Discovery of thematic areas. The research themes are analyzed using an evolution map (Fig. 1 (b)), which links the themes that maintain a conceptual nexus across consecutive periods.

- Performance analysis. The relative contribution of research themes and thematic areas to the entire field of research is measured quantitatively and qualitatively. This can then be used to identify the most productive and relevant areas within the field.

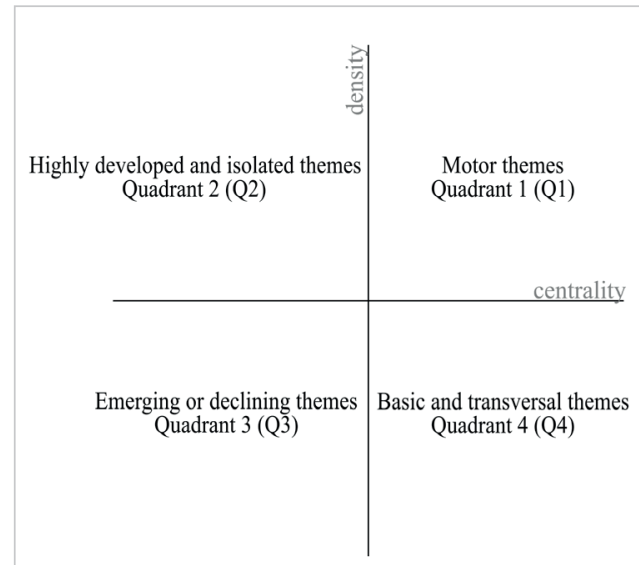

(a)

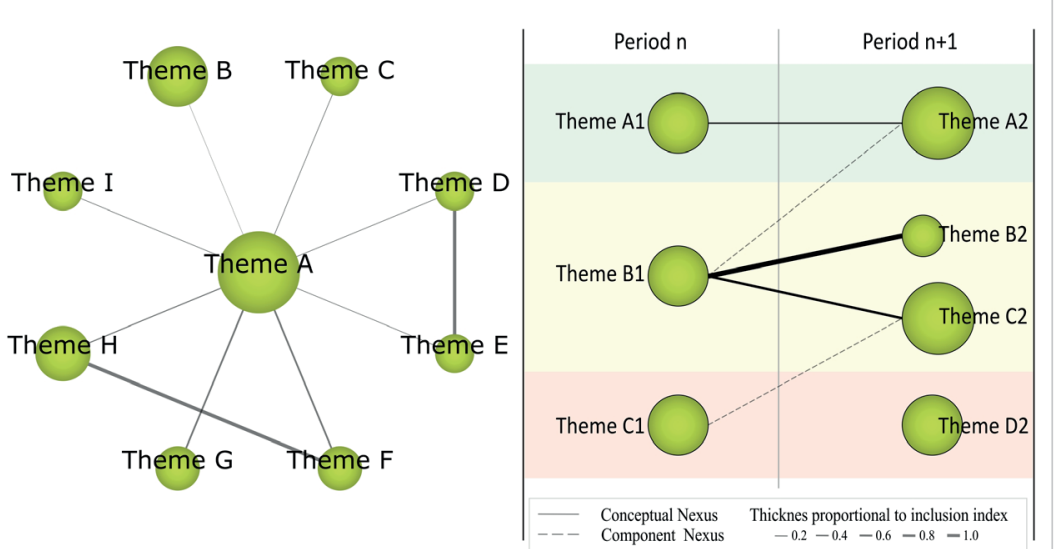

(b) (c)

Figure 1. (a) Strategic diagram, (b) thematic network, and (c) thematic evolution

In addition to science mapping analysis, the present research seeks to identify the citation classics, that is, highly cited articles. For this purpose, the concept of $\mathrm{H}$-Classics proposed by Martínez et al. (2014) was used, which can be defined as follows: " $\mathrm{H}$-Classics of a research area ' $\mathrm{A}$ ' could be defined as the $\mathrm{H}$-core of ' $\mathrm{A}$ ' that is composed of the ' $\mathrm{H}$ ' highly cited papers with more than ' $H$ ' citations received" (Martínez et al., 2014).

\subsection{Dataset}

Publications related to the various types of coronavirus were collected to analyze their bibliometric characteristics and perform science mapping. In this regard, different corpora and queries have been proposed to retrieve articles related to Covid-19 from different databases. In this analysis, we focus on the queries proposed for Web of Science (WoS), and specially follow the advice suggested in the ISSI distribution list. The present study thus focuses on the following concepts: coronavirus and severe acute respiratory syndrome coronavirus.

As a consequence, the raw data (publications) were collected using the WoS, since it is the most important database, covering a wide range of disciplines and thus enabling comparisons across scientific areas. Therefore, the research publications dedicated to the main coronavirus types and themes mentioned above were downloaded from the Web of Science Core Collection using the following advanced query:

TS=("Wuhan coronavirus" OR "Wuhan seafood market pneumonia virus" OR "Covid19*" OR "Covid-19*" OR "Covid-2019*" OR "coronavirus disease 2019" OR "SARS-CoV-2" OR "sars2" OR "2019-nCoV" OR "2019 novel coronavirus" OR "severe acute respiratory syndrome coronavirus 2" OR "2019 novel coronavirus infection" OR "coronavirus disease 2019" OR "coronavirus disease-19" OR "novel coronavirus" OR "coronavirus" OR "SARS-CoV-2019" OR "SARS-CoV-19").

Refined by: DOCUMENT TYPES: (ARTICLE OR PROCEEDINGS PAPER OR REVIEW) AND LANGUAGES: (ENGLISH). Timespan: All years. Indexes: SCI-EXPANDED, SSCI, A\&HCI, CPCI-S, CPCI-SSH, BKCI-S, BKCI-SSH, ESCI, CCR-EXPANDED, IC. 
This query retrieved a total of 12,571 publications from 1970 to 2020. The corpus was further refined and limited to the English language and the following publication types: articles, proceedings, and reviews. The citations of these publications were also used in this work, being collected up to April 18, 2020.

After importing this raw data into SciMAT, a deduplication process was also applied to improve the data quality, by grouping meanings and concepts that represent the same notion (e.g., "SEVERE-ACUTE-RESPIRATORY-SYNDROME CORONAVIRUS", "SEVERE-ACUTE-RESPIRATORY-SYNDROME-CORONAVIRUS-(SARS-COV)" and "SARS-CoV" were merged to "SEVERE-ACUTE-RESPIRATORY-SYNDROME-CORONAVIRUS").

As a second step, and to avoid flatness of the data, the whole span of years was split into consecutive periods. While such periods frequently cover the same time spans, given the low number of publications in the early years, the best option was to divide the time span into comparable periods. Therefore, the study period (1970-2020) was split into three consecutive time periods: 1970-1999, 2000-2009, and 2010-2020 with 1,797, 4,129, and 6,645 publications, respectively.

\section{Bibliometric analysis of coronavirus research}

This section deals with the evolution of the coronavirus in terms of publications, citations, and impact by analyzing the following bibliometric indicators: published documents, received citations, journal impact factors, most cited publications, most cited authors, h-index, research areas, and data on the geographic distribution of publications.

The bibliometric performance analysis is therefore structured into three sections: production and impact of published documents; production and impact of authors, journals, and research areas; and $\mathrm{H}$-Classics analysis.

\subsection{Publications and citations}

Figure 2 shows the distribution of publications and citations related to coronavirus types and strains per year for the defined periods. Firstly, it should be noted that Figure 2 shows that the values of these indicators have increased over the last year.

Since the appearance of the first publications related to coronavirus in 1970, three milestones in the development of such literature can be observed. The first milestone corresponds to the first 35 years (1970-2005), during which the rate of publications increased, reaching a total of 3,187 (25.11\% of the total). This development profile reveals the growing interest in coronavirus within the scientific community and includes the emergence of the SARS disease in 2002 and 2003. In this analysis, the second milestone corresponds to the drop from 2005 to 2011, during which only 3,554 documents were published, representing $28.27 \%$ of the publications from 1970 to 2020 . Finally, the last year (2020) represents the last milestone, during which 1,009 publications ( $8.03 \%$ of the total) were produced in only four months and marking the historical peak in this research field.

Similarly, the distribution of citations shows a positive developmental trend during the period from 1970 to 2020 , during which a total of 382,447 citations (including self-citations) were recorded. Finally, WoS indicates that the average number of citations per cited article is 40.08 . Complementing these data, the first significant increase in citations appears at the beginning of this century, when the number of citations exhibited a higher growth rate. In subsequent years, the average of the citation distribution rose continuously.

Finally, it should be mentioned that the publications during the three stated period generated a total of 83,414 187,549 , and 111,484 citations, respectively. Nonetheless, note that the total number of citations appears to show a downward trend over the past six years, although this is not a real trend. According to Wang (2013), the
The number of publications in the last year (2020) has reached 1,009 (8.03\% of the total) in only four months, marking the historical peak in this research field 
most cited publications are generally those published in previous years due to the time span between publication and reference. It is estimated that a publication needs between 3 and 7 years to reach its highest number of citations. Furthermore, given the observed pattern of development, it can be assumed that this positive trend will continue.

\subsection{Most productive and cited authors, geographic distribution of publications, and research areas}

It is also important to determine the most productive and cited authors, along with the research areas and the geographic distribution of publications and organizations, which can support an evaluation of the evolution of the research field. Table 1 shows the most productive authors (with more than 100 publications) and most cited authors (with more than 7,000 citations) during the period from 1970 to 2020.

Because ties were observed for some positions, such authors are listed in alphabetical order.

In addition, Table 1 reveals that, according to WoS, seven of the most productive authors are also among those most widely cited: Yuen (201 publications; 16,710 citations), Enjuanes (162; 7,273), Drosten (127; 10,692), Rottier (124; 7,281), Woo (112; 7,292), Chan (111; 11,651), and Snijder (104; 7,888).

In the same way, Table 2 lists the most productive countries (with more than 400 publications) and organizations (with than 190 publications) related to coronavirus research during the period from 1970 to 2020.

Table 1. Most productive authors (1970-2020)

\begin{tabular}{|c|l|c|l|}
\hline Publications & \multicolumn{1}{|c|}{ Author } & Citations & \multicolumn{1}{|c|}{ Author } \\
\hline 201 & Yuen & 16,710 & Yuen \\
\hline 169 & Perlman & 11,651 & Chan \\
\hline 162 & Baric; Enjuanes & 10,692 & Drosten \\
\hline 133 & Weiss & 10,158 & Osterhaus \\
\hline 127 & Drosten & 10,108 & Peiris \\
\hline 124 & Rottier & 9,516 & Guan \\
\hline 112 & Woo & 8,501 & Poon \\
\hline 111 & Chan; Saif & 7,888 & Snijder \\
\hline 105 & Lau & 7,292 & Woo \\
\hline 104 & Snijder & 7,281 & Rottier \\
\hline- & - & 7,273 & Enjuanes \\
\hline
\end{tabular}

Table 2. Most productive countries (1970-2020)

\begin{tabular}{|c|l|c|l|}
\hline Publications & \multicolumn{1}{|c|}{ Country } & Publications & \multicolumn{1}{|c|}{ Organization } \\
\hline 4,513 & United States & 487 & University of Hong Kong \\
\hline 2,746 & China & 373 & Chinese Academy of Sciences \\
\hline 962 & United Kingdom & 321 & University of California System \\
\hline 797 & Germany & 296 & National Institutes of Health USA; Utrecht University \\
\hline 712 & Netherlands & 257 & University of North Carolina \\
\hline 687 & Canada & 231 & Centers for Disease Control Prevention USA \\
\hline 582 & Japan & 215 & University of Texas System \\
\hline 491 & France & 214 & University of North Carolina Chapel Hill \\
\hline 469 & South Korea & 195 & University of Pennsylvania \\
\hline 417 & Italy & 194 & Chinese University of Hong Kong \\
\hline 403 & Taiwan & & \\
\hline
\end{tabular}

During the period from 1970 to 2020, the USA appears to be the most productive country, with 4,513 publications, followed by the People's Republic of China and the UK with 2,746 and 962 publications, respectively, although countries such as Germany, the Netherlands, Canada, and Japan also recorded significant numbers.

Table 3 shows the most relevant WoS subject categories (with more than 400 publications) and research areas (with more than 400 publications) during the period from 1970 to 2020.

Table 3. Most relevant WoS subject categories and research areas (1970-2020)

\begin{tabular}{|c|l|c|l|}
\hline Publications & \multicolumn{1}{|c|}{ WoS subject categories } & Publications & \multicolumn{1}{|c|}{ Research areas } \\
\hline 4,089 & Virology & 4,089 & Virology \\
\hline 1,731 & Veterinary Sciences & 1,731 & Veterinary Sciences \\
\hline 1,392 & Immunology & 1,455 & Biochemistry Molecular Biology \\
\hline 1,387 & Infectious Diseases; Microbiology & 1,392 & Immunology \\
\hline 1,218 & Biochemistry Molecular Biology & 1,387 & Infectious Diseases; Microbiology \\
\hline 747 & Biotechnology Applied Microbiology & 747 & Biotechnology Applied Microbiology \\
\hline 643 & Medicine Research Experimental & 643 & Research Experimental Medicine \\
\hline 540 & Multidisciplinary Sciences & 576 & Science Technology other Topics \\
\hline 426 & Public Environmental Occupational Health & 565 & Pharmacology Pharmacy \\
\hline 404 & Pharmacology Pharmacy & 446 & General Internal Medicine \\
\hline & & 426 & Public Environmental Occupational Health \\
\hline
\end{tabular}


Finally, Table 4 lists the journals with the highest numbers of publications (more than 200), highlighting the diversity of the journals that host the main publications, including subjects from virology to biology.

Table 4. Journals with the highest numbers of publications (1970-2020)
During the period from 1970 to 2020, the USA was the most productive country, with 4,513 publications, followed by China and the UK

\begin{tabular}{|l|c|c|c|c|c|}
\hline \multicolumn{1}{|c|}{ Name } & $\begin{array}{c}\text { Publications } \\
\text { related to } \\
\text { coronavirus }\end{array}$ & $\begin{array}{c}\text { Total cites (cita- } \\
\text { ble items 2018) }\end{array}$ & $\begin{array}{c}\text { Journal Impact } \\
\text { Factor (JIF- } \\
\text { 2018) }\end{array}$ & $\begin{array}{c}\text { 5-Year Impact } \\
\text { Factor }\end{array}$ & $\begin{array}{c}\text { Immediacy } \\
\text { Index } \\
\text { without Jour- } \\
\text { nal Self Cites }\end{array}$ \\
\hline Journal of Virology & 1,134 & $88,684(802)$ & 4.324 & 4.259 & 1.185 \\
\hline Virology & 480 & $25,009(312)$ & 2.657 & 3.315 & 2.800 \\
\hline $\begin{array}{l}\text { Advances in Experimental } \\
\text { Medicine and Biology }\end{array}$ & 349 & $7,609(394)$ & 0.663 & 0.778 & 0.236 \\
\hline Journal of General Virology & 316 & $18,927(180)$ & 2.809 & 2.851 & 0.65 \\
\hline Archives of Virology & 257 & $10,715(447)$ & 2.261 & 2.134 & 0.728 \\
\hline Virus Research & 244 & $9,137(294)$ & 2.736 & 2.667 & 2.702 \\
\hline Plos One & 238 & $650,727(17,879)$ & 2.776 & 3.37 & 2.015 \\
\hline
\end{tabular}

Bearing in mind the results presented above, the most relevant authors and publications are analyzed below in terms of citations according to the $\mathrm{h}$-index and $\mathrm{H}$-Classics.

\subsection{Citation classics}

The H-Classics method (Martínez et al., 2014), based on the well-known h-index (Hirsch, 2005), serves as an impartial criterion to identify classic papers in any research field. Thus, in this section, the H-Classics method is applied to identify classical papers in the coronavirus research field and thereby the authors, countries, and journals making the greatest contributions.

The search query used in the WoS Core Collection database has an h-index of 192. Using this h-index score as a reference, the relevant publications were identified and are listed in Table A.1. In terms of citations, their distribution shows a positive developmental trend. Thus, a total of 72,763 citations (including self-citations) were recorded, and the average number of citations per cited article is 378.97 . Thus, the total number of citations and the distribution of the most relevant classic publications from 1970 to 2020 are shown in Figure 3.

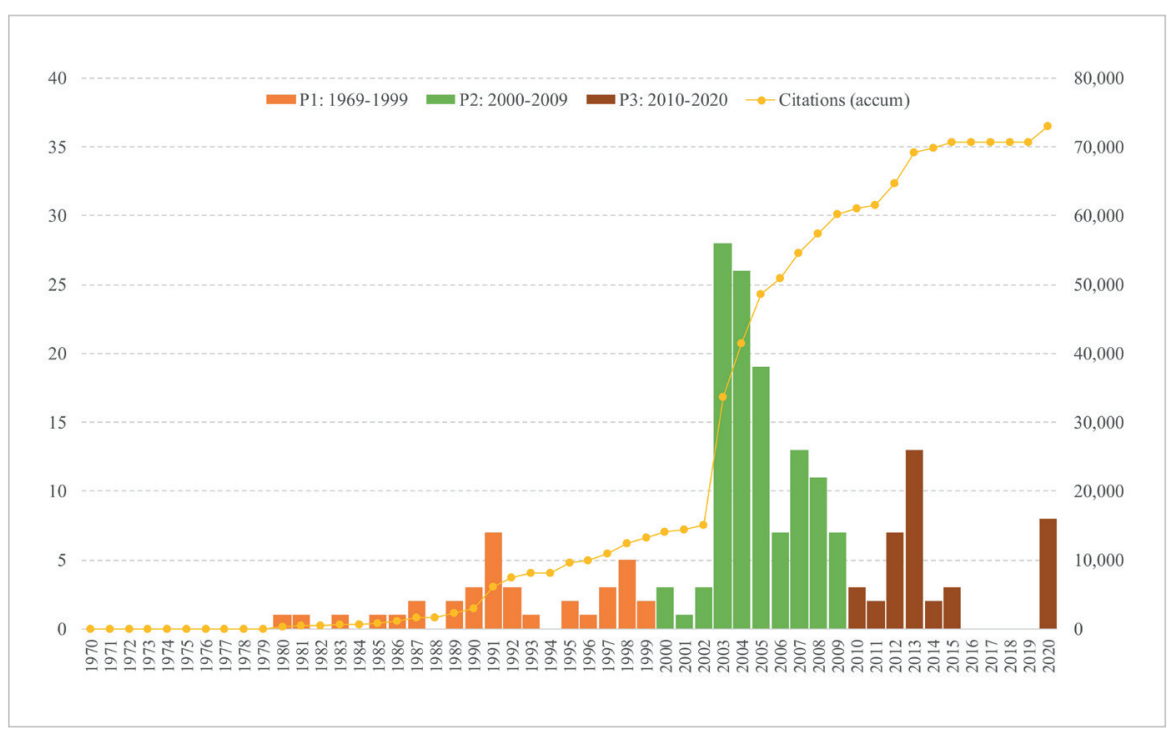

Figure 3. Distribution of most relevant publications by year (1970-2020)

Figure 3 shows that there are publications that remain as references after the 7-year period has elapsed, implying that they form part of the core of the coronavirus research field (Wang, 2013). Similarly, during the early twenty-first century, the distribution of the most cited articles reached its highest values, in contrast to the fact that this decade showed relatively low productivity.

In addition, Table 5 lists the authors with the highest numbers of publications used as references, and their citations. Twenty-seven authors have five or more publications in the list of most cited articles in recent years. Also, ten authors included in the tables of the most productive and cited authors are included in Table 5.
The journals with the highest numbers of publications related to coronavirus are: Journal of Virology, Virology, and Advances in Experimental Medicine and Biology 
Table 5. Authors with the highest numbers of cited publications.

\begin{tabular}{|c|c|}
\hline Publications & Author (Citations) \\
\hline 15 & Yuen $(7,875)$ \\
\hline 13 & Chan $(6,300)$ \\
\hline 12 & Osterhaus $(8,044)$ \\
\hline 11 & Peiris $(6,437)$ \\
\hline 10 & Guan $(6,090)$ \\
\hline 9 & Snijder $(3,348)$ \\
\hline 8 & Drosten $(5,343)$; Fouchier $(5,403)$; Gorbalenya $(3,058)$; Poon $(5,505)$ \\
\hline 7 & Farzan (2,639); Holmes (2,368); Ziebuhr $(2,913)$ \\
\hline 6 & Haagmans (1,992); Lai $(2,065) ;$ Lau (2,306); Li $(2,395) ;$ Lim $(5,543) ;$ Rottier $(1,797)$; Woo $(2,306)$; Zheng $(2,912)$ \\
\hline 5 & Choe (2,083); Daszak (2,078); Subbarao (1,390); Thiel $(2,278)$; Tsoi $(2,322)$; Zhang $(1,500)$ \\
\hline
\end{tabular}

Regarding production by country, the USA accounts for approximately $48.95 \%$ (94 publications) of the cited articles, followed by the People's Republic of China (23.43\%, 45 publications), the UK (14.58\%, 28 publications), and Germany (13.54\%, 26 publications). These data strongly agree with the results presented in the tables described above.

Similarly, the most relevant WoS subject categories (with more than 10 publications) and research areas (with more than 10 publications) for $\mathrm{H}$-Classics publications are presented in Table 6.

Table 6. WoS subject categories and research areas for h-index publications

\begin{tabular}{|c|l|c|l|}
\hline Publications & WoS subject categories & Publications & Research areas \\
\hline 46 & Virology & 46 & Virology \\
\hline 39 & Multidisciplinary Sciences & 39 & Science Technology other Topics \\
\hline 29 & Medicine General Internal & 30 & General Internal Medicine \\
\hline 28 & Biochemistry Molecular Biology & 29 & Biochemistry Molecular Biology \\
\hline 27 & Microbiology & 27 & Microbiology \\
\hline 14 & Cell Biology; Infectious Diseases & 14 & Cell Biology; Infectious Diseases \\
\hline 12 & Immunology & 12 & Immunology \\
\hline
\end{tabular}

Finally, among the journals listed in Table 4 and the journals identified in this section, only two appear in both sections: Virology (with 6 publications) and Journal of General Virology (with 5 publications). Furthermore, the most relevant sources within the H-Classics publications are: Proceedings of The National Academy of Sciences of the United States of America (16 publications), Lancet (15), Nature (14), New England Journal of Medicine (12), Science (9), Nature Medicine (6), Journal of Clinical Microbiology (5), and Lancet Infectious Diseases (5).

\section{Science mapping analysis of coronavirus}

Next, an overview of the key themes in the main research fields related to coronavirus is provided based on science mapping analysis, being structured into two complementary sections: content analysis of the articles published, and a conceptual evolution map. The former supports the identification of the themes arising in the coronavirus literature, its main types and strains, and its evolution in the literature for each period, whereas the latter shows both the development of these themes and the relationships between them for the entire period of analysis.

\subsection{Content analysis}

Three strategic diagrams are shown in the following figures to analyze the most important themes within the coronavirus literature for each period. Based on their centrality and density, the research themes have been classified into four categories. Furthermore, in the strategic diagrams, the research themes are represented as spheres whose volume is proportional to the corresponding number of publications.

During the period from 1970 to 1999, sixteen research themes related to coronavirus could be identified, as shown in the strategic diagram and the performance indicators (number of publications, citations achieved, and h-index) of the themes during this period (Figure. 4(a)). Eight research themes are considered to be key because of their contribution to the growth of knowledge about coronavirus (motor themes and basic and transversal themes): BOVINE-CORONAVIRUS, ENDOPLASMIC-RETICULUM, TRANSMISSIBLE-GASTROENTERITIS-VIRUS, LELYSTAD-VIRUS, INFECTIOUS-BRONCHITIS-VIRUS, CORONAVIRUS-JHM, ENTERIC-CORONAVIRUS, and SINDBIS-VIRUS.

Based on the number of citations and h-index, the main research themes directly related to the coronavirus types and strains for this period are as follows: CORONAVIRUS-JHM, ENDOPLASMIC-RETICULUM, INFECTIOUS-BRONCHITIS-VIRUS, TRANSMISSIBLE-GASTROENTERITIS-VIRUS, and ENTERIC-CORONAVIRUS. It is important to mention that the main research themes identified are included in the key themes (motor themes and basic and transversal themes). 


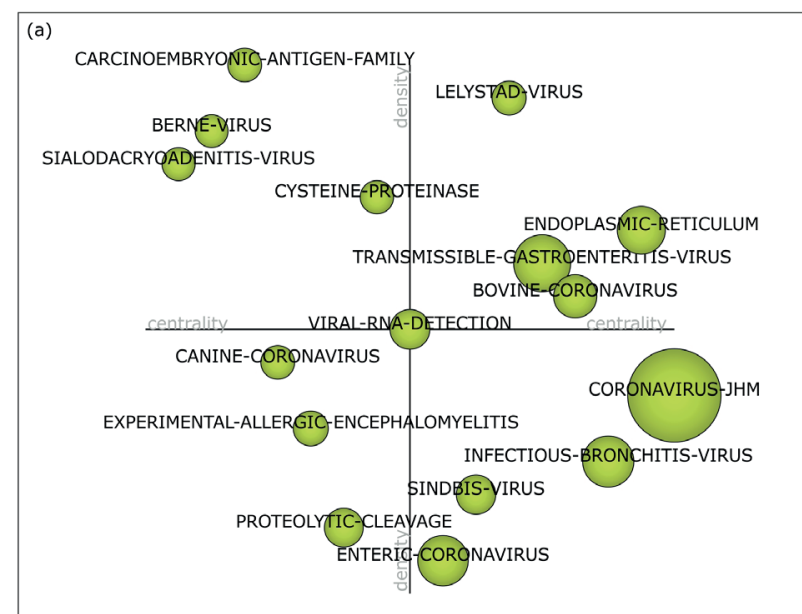

\begin{tabular}{|c|c|c|c|c|c|}
\hline Theme & Cuadrant & Documents & Citations & 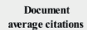 & Ir-index \\
\hline ENDOPLASMIC-RETICULUM & Q1 & 151 & 10,177 & 67.41 & 56 \\
\hline TRANSMISSIBLEGASTRROENTERTIS-YRUS & al & 231 & 9.463 & 40.97 & 53 \\
\hline BOYNE-CORONA VRIS & Q1 & 108 & 4,485 & 41.53 & 41 \\
\hline LELYSTAD-VIRUS & Q1 & 27 & 2914 & 10793 & 18 \\
\hline URALRNA.DEEECTION & Q2 & 78 & 4,580 & 58.72 & 43 \\
\hline CARCNOEMBPYONCAANTGERN-FAMILY & 02 & 24 & 1.255 & 52.29 & 17 \\
\hline CXSTENE-PROTENASE & Q2 2 & 20 & 945 & 47.25 & 15 \\
\hline BRRNEVRRUS & $\mathrm{Q}^{2}$ & 16 & 698 & 43.62 & 11 \\
\hline SIALODACRYOADENITIS-VRUS & $\mathrm{Q}_{2}$ & 18 & 152 & 844 & 8 \\
\hline PROTEOLYTIC-CIEAVAGE & $Q^{3}$ & 69 & 2.696 & 39.07 & 31 \\
\hline EXPRRIMENTALALALRGGC.ENCFPHALOMYEUTIS & $Q^{3}$ & 35 & 22993 & 6.51 & 22 \\
\hline CANNE-CORONA VRUS & $Q^{3}$ & 24 & 827 & 34.46 & 15 \\
\hline CORONA VRUS. JM & 04 & 554 & 24,43 & 44.12 & 80 \\
\hline INFECTIOUS-BRONAIITIS-MIRUS & Q4 & 179 & 9,735 & 54.39 & 56 \\
\hline ENTERC-CORONAYVRLS & at & 173 & 6083 & 35.16 & 46 \\
\hline SINDBSS-TRIS & Q4 & 74 & 4.279 & 57.82 & 39 \\
\hline
\end{tabular}
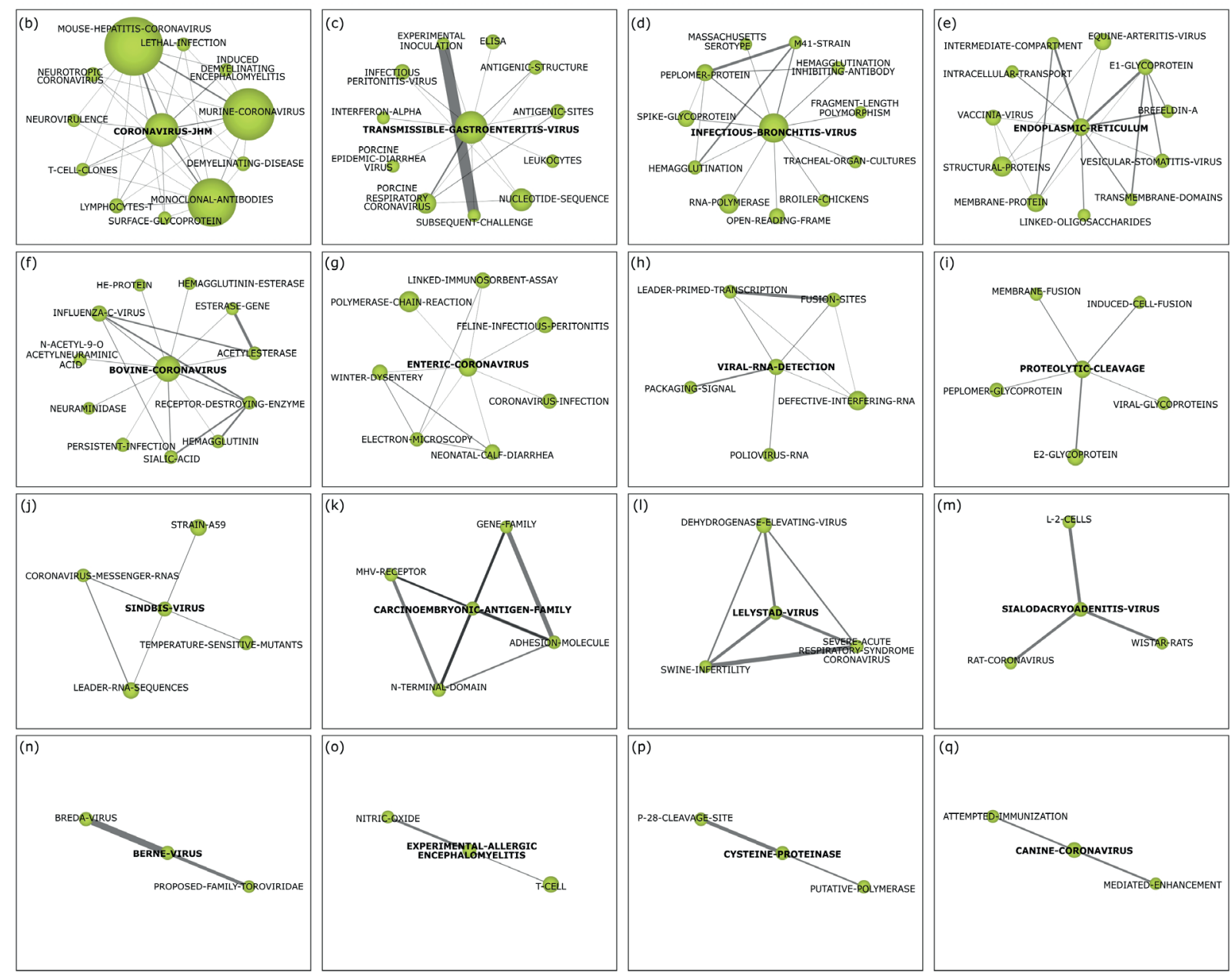

Figure 4. (a) Strategic diagram and performance from 1970 to 1999. Thematic networks, (b) CORONAVIRUS-JHM. (c) TRANSMISSIBLEGASTROENTERITIS-VIRUS. (d) INFECTIOUS-BRONCHITIS-VIRUS. (e) ENDOPLASMIC-RETICULUM. (f) BOVINE-CORONAVIRUS. (g) ENTERIC-CORONAVIRUS. (h) VIRAL-RNA-DETECTION. (i) PROTEOLYTIC-CLEAVAGE. (j) SINDBIS-VIRUS. (k) CARCINOEMBREYONIC-ANTIGEN-FAMILY. (I) LELYSTAD-VIRUS. (m) SIALODRACRYOADENITIS-VIRUS. (n) BERNE-VIRUS. (o) EXPERIMENTAL-ALLERGIC-ENCEPHALOMYELITIS. (p) CYSTEINE-PROTEINASE. (q) CANINECORONAVIRUS.

During the second period, from 2000 to 2009, sixteen research themes related to coronavirus could be identified, as shown in the strategic diagram and the performance indicators (number of publications, citations achieved, and h-index) of the themes in this period (Figure. 5 (a)). Eight research themes are considered to be key because of their contribution to the growth of the knowledge about coronavirus (motor themes and basic and transversal themes): CORONAVIRUS-MAIN-PROTEINASE, HUMAN-METAPNEUMOVIRUS, MOUSE-HEPATITIS-CORONAVIRUS, MONOCLONAL-ANTIBODIES, MULTIPLE-SCLEROSIS, POLYMERASE-CHAIN-REACTION, NUCLEOCAPSID-PROTEIN, and TRANSMISSIBLE-GASTROENTERITIS-CORONAVIRUS.

Based on the number of citations and $h$-index, the main research themes directly related to cornavirus this period are as follows: MOUSE-HEPATITIS-CORONAVIRUS, MONOCLONAL-ANTIBODIES, NUCLEOCAPSID-PROTEIN, POLYMERA- 


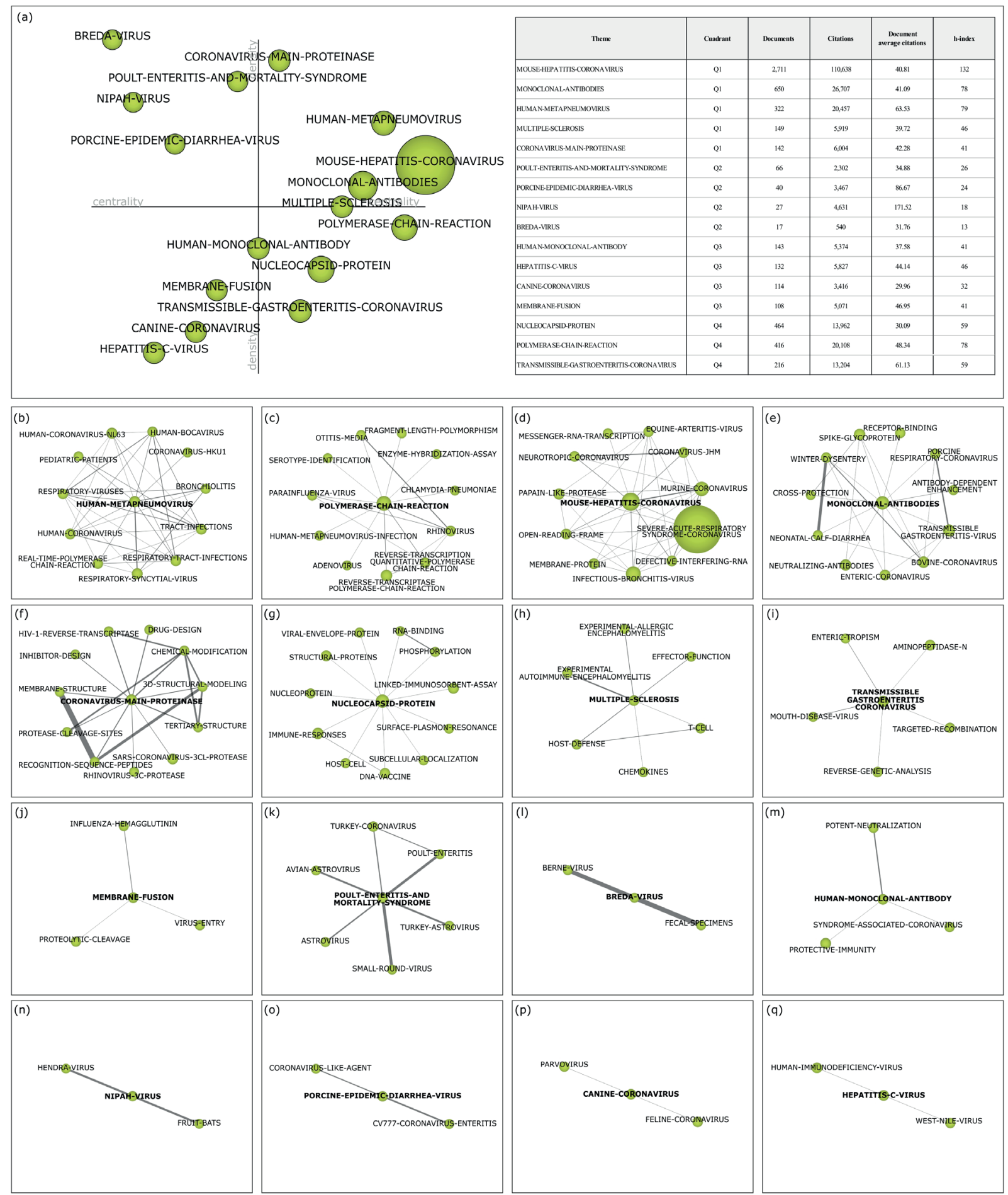

Figure 5. (a) Strategic diagram and performance from 2000 to 2009. Thematic networks. (b) HUMAN-METAPNEUMOVIRUS. (c) POLYMERASE-CHAINREACTION. (d) MOUSE-HEPATITIS-CORONAVIRUS. (e) MONOCLONAL-ANTIBODIES. (f) CORONAVIRUS-MAIN-PROTEINASE. (g) NUCLEOCAPSIDPROTEIN. (h) MULTIPLE-SCLEROSIS. (i) GASTROENTERITIS-CORONAVIRUS. (j) MEMBRANE-FUSION. (k) POULT-ENTERITIS-AND-MORTALITY-SINDROME. (I) BREDA-VIRUS. (m) HUMAN-MONOCLONAL-ANTIBODY. (n) NIPAH-VIRUS. (o) PORCINE-EPIDEMIC-DIARRHEA-VIRUS. (p) CANINE-CORONAVIRUS. (q) HEPTITIS-C-VIRUS.

SE-CHAIN-REACTION, and HUMAN-METAPNEUMOVIRUS. As they did in the previous period (1970-1999), the main research themes identified in this period are included in the key themes.

Compared with the previous period, the motor themes retain four themes and incorporate one new theme. Furthermore, CANINE-CORONAVIRUS is the only theme that appears in the first and second period. In this way, the intellectual structure includes themes in all quadrants (motor themes (5), highly developed and isolated themes (4), emerging or declining themes (4), and basic and transversal themes (3)).

Finally, during the third period (2010 to 2020), sixteen research themes related to the coronavirus could be identified, as shown in the strategic diagram and the performance indicators (number of publications, citations achieved, and h-index) of the themes in this period (Figure. 6 (a)). In this regard, eight research themes are considered to be key because 


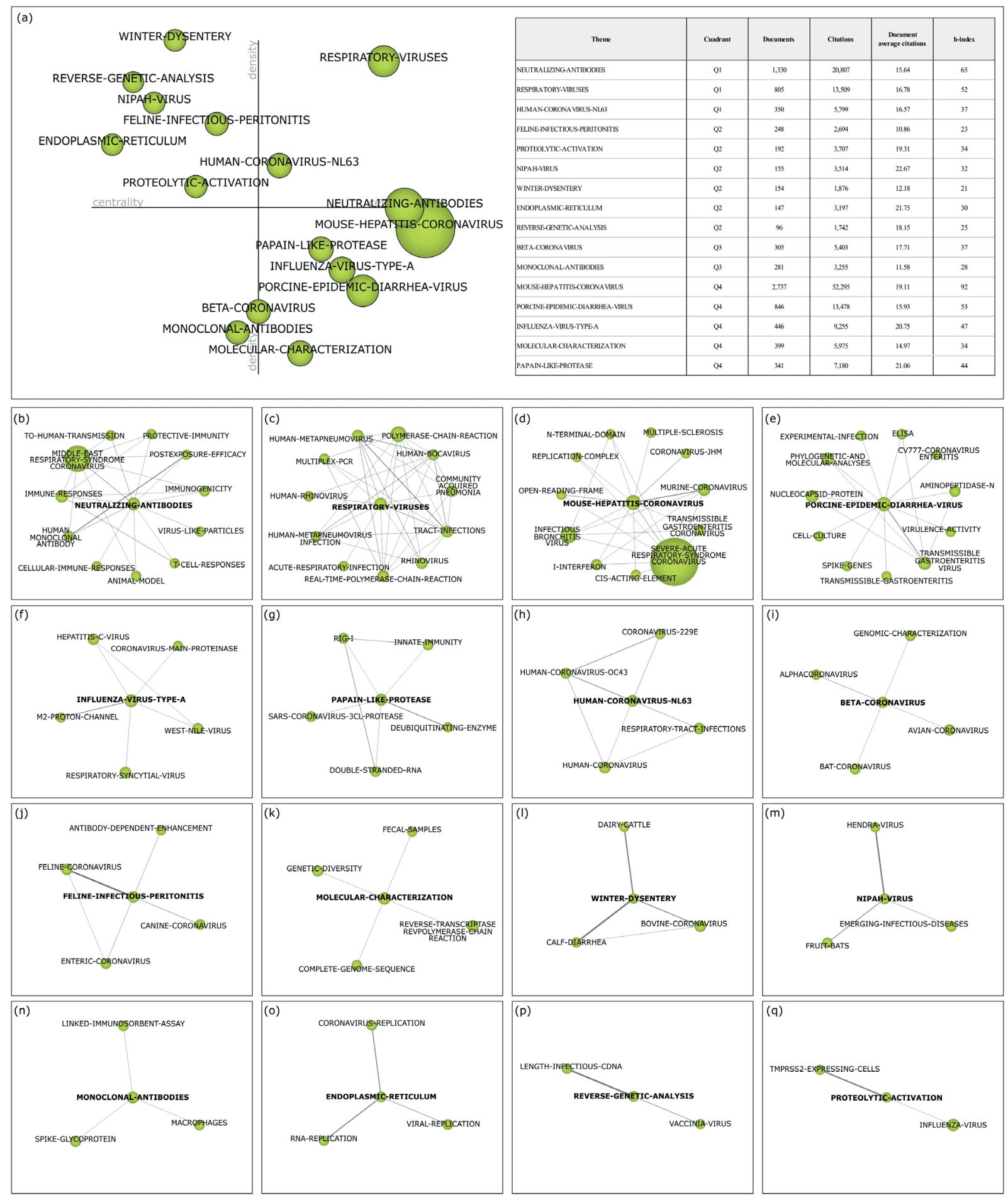

Figure 6. (a) Strategic diagram and performance from 2010 to 2020. Thematic networks. (b) NEUTRALIZING-ANTIBODIES. (c) RESPIRATORY-VIRUSES. (d) MOUSE-HEPATITIS-CORONAVIRUS. (e) PORCINE-EPIDEMIC-DIARRHEA-VIRUS. (f) INFLUENZA-VIRUS-TYPE-A. (g) PAPAIN-LIKE-PROTEASE. (h) HUMANCORONAVIRUS-NL63. (i) BETA-CORONAVIRUS. (j) FELINE-INFECTIOUS-PERITONITIS. (k) MOLECULAR-CHARACTERIZATION. (I) WINTER-DYSENTERY. (m) NIPAH-VIRUS. (n) MONOCLONAL-ANTIBODIES. (o) ENDOPLASMIC-RETICULUM. (p) REVERSE-GENETIC-ANALYSIS. (q) PROTOELYTIC-ACTIVATION.

of their contribution to the growth of knowledge about coronavirus (motor themes and basic and transversal themes): RESPIRATORY-VIRUSES, NEUTRALIZING-ANTIBODIES, HUMAN-CORONAVIRUS-NL63, MOUSE-HEPATITIS-CORONAVIRUS, PORCINE-EPIDEMIC-DIARRHEA-VIRUS, PAPAIN-LIKE-PROTEASE, INFLUENZA-VIRUS-TYPE-A, and MOLECULAR-CHARACTERIZATION.

Based on the number of citations and h-index, the main research themes directly related to cornavirus this period are as follows: MOUSE-HEPATITIS-CORONAVIRUS, NEUTRALIZING-ANTIBODIES, PORCINE-EPIDEMIC-DIARRHEA-VIRUS, RESPIRATORY-VIRUSES, and INFLUENZA-VIRUS-TYPE-A. In the period from 2010 to 2020, as in the previous period, the main research themes identified are included in the key themes.

Compared with the previous period, the motor themes retain three and lose two. Furthermore, ENDOPLASMIC-RETICULUM, MOUSE-HEPATITIS-CORONAVIRUS, NUCLEOCAPSID-PROTEIN, PORCINE-EPIDEMIC-DIARRHEA-VIRUS, and NI- 
PAH-VIRUS are the themes that appear in the first, second, and third periods. In this way, the intellectual structure includes themes in all four quadrants (motor themes (3), highly developed and isolated themes (6), emerging or declining themes (2), and basic and transversal themes (5)).

Finally, taking into account the strategic diagrams shown in Figures 4, 5, and 6, Table 7 summarizes the main research themes developed and their performance according to the number of publications from 1970 to 2020 .

Table 7. Principal research themes related to coronavirus from 1970 to 2020

\begin{tabular}{|c|c|c|c|}
\hline Theme & P1: 1969-1999 & P2: 2000-2009 & P3: 2010-2020 \\
\hline CORONAVIRUS-JHM & Q4 (554 | 24,443 | 80) & & \\
\hline TRANSMISSIBLE-GASTROENTERITIS-VIRUS & Q1 (231 | 9,463 | 53) & & \\
\hline INFECTIOUS-BRONCHITIS-VIRUS & Q4 (179 | 9,735 | 56) & & \\
\hline ENTERIC-CORONAVIRUS & Q4 (173 | 6,083 | 46) & & \\
\hline ENDOPLASMIC-RETICULUM & Q1 (151| 10,179|56) & & Q2 (147| 3,197|30) \\
\hline BOVINE-CORONAVIRUS & Q1 (108|4,485 |41) & & \\
\hline PROTEOLYTIC-CLEAVAGE & Q3 (69 | 2,696 | 31) & & \\
\hline VIRAL-RNA-DETECTION & Q2 (78 $4,580 \mid 43)$ & & \\
\hline SINDBIS-VIRUS & Q4 (74 | 4,279 | 39) & & \\
\hline EXPERIMENTAL-ALLERGIC-ENCEPHALOMYELITIS & Q3 (35 | 2,293 | 22) & & \\
\hline LELYSTAD-VIRUS & Q1 (27| 2,914|18) & & \\
\hline CANINE-CORONAVIRUS & Q3 (24 | 827 | 15) & Q3 (114 | 3,416 | 32) & \\
\hline CARCINOEMBRYONIC-ANTIGEN-FAMILY & Q2 (24 | 1,255 | 17) & & \\
\hline CYSTEINE-PROTEINASE & Q2 (20 | $945 \mid 15)$ & & \\
\hline SIALODACRYOADENITIS-VIRUS & $\mathrm{Q} 2(18|152| 8)$ & & \\
\hline BERNE-VIRUS & Q2 (16 $|698| 11)$ & & \\
\hline MOUSE-HEPATITIS-CORONAVIRUS & & Q1 $(2,711|110,638| 132)$ & Q4 $(2,737|52,295| 92)$ \\
\hline MONOCLONAL-ANTIBODIES & & Q1 (650 | 26,707 | 78) & Q3 (281 | 3,255 | 28) \\
\hline NUCLEOCAPSID-PROTEIN & & Q4 (464 | 13,962 | 59) & \\
\hline POLYMERASE-CHAIN-REACTION & & Q4 (416 | 20,108 | 78) & \\
\hline HUMAN-METAPNEUMOVIRUS & & Q1 (322 | 20,457| 79) & \\
\hline TRANSMISSIBLE-GASTROENTERITIS-CORONAVIRUS & & Q4 (216 | 13,204 | 59) & \\
\hline MULTIPLE-SCLEROSIS & & Q1 (149|5,919|46) & \\
\hline HUMAN-MONOCLONAL-ANTIBODY & & Q3 (143 | 5,374 | 41) & \\
\hline CORONAVIRUS-MAIN-PROTEINASE & & Q1 (142 | 6,004 | 41) & \\
\hline HEPATITIS-C-VIRUS & & Q3 (132|5,827|46) & \\
\hline MEMBRANE-FUSION & & Q3 (108 | 5,071 | 41) & \\
\hline POULT-ENTERITIS-AND-MORTALITY-SYNDROME & & Q2 (66 | 2,302 | 26) & \\
\hline PORCINE-EPIDEMIC-DIARRHEA-VIRUS & & $\mathrm{Q} 2(40|3,467| 24)$ & Q4 (846 | 13,478 | 53) \\
\hline NIPAH-VIRUS & & Q2 (27 | 4,631 | 18) & Q2 (155|3,514|32) \\
\hline BREDA-VIRUS & & Q2 (17| 540|13) & \\
\hline NEUTRALIZING-ANTIBODIES & & & Q1 $(1,330|20,807| 65)$ \\
\hline RESPIRATORY-VIRUSES & & & Q1 (805 | 13,509|52) \\
\hline INFLUENZA-VIRUS-TYPE-A & & & Q4 (446 | 9,255 | 47) \\
\hline MOLECULAR-CHARACTERIZATION & & & Q4 (399|5,975 | 34) \\
\hline HUMAN-CORONAVIRUS-NL63 & & & Q1 (350|5,799|37) \\
\hline PAPAIN-LIKE-PROTEASE & & & Q4 (341 | 7,180 | 44) \\
\hline BETA-CORONAVIRUS & & & Q3 (305 | 5,403 | 37) \\
\hline FELINE-INFECTIOUS-PERITONITIS & & & Q2 (248 | 2,694 | 23) \\
\hline PROTEOLYTIC-ACTIVATION & & & Q2 (192 | 3,707 | 34) \\
\hline WINTER-DYSENTERY & & & $\mathrm{Q} 2(154|1,876| 21)$ \\
\hline REVERSE-GENETIC-ANALYSIS & & & Q2 (96 | 1,742 | 25) \\
\hline
\end{tabular}




\subsection{Conceptual evolution map}

The themes detected in each period can be jointly analyzed by means of their conceptual evolution, that is, discovering the shared terms and how they evolve through time. Thus, using as input the themes of the three consecutive time periods, a second analysis focusing on the conceptual evolution was carried out.

Hence, two thematic areas were identified: virus and coronavirus complementary research and virus and coronavirus types and strains. These thematic areas consolidate the main themes and research areas related to coronavirus. Figure 7 shows the conceptual evolution map and lists the key performance indicators for each thematic area.

Virus and coronavirus types and strains (pink area) is the most representative thematic area within the conceptual evolution map (Figure 7). It accounts for 11,029 publications, 333,082 of the total citations, and 132 publications highly cited according to the h-index. In terms of structure and thematic composition, it contains motor themes, highly developed and isolated themes, and basic and transversal themes in all the periods, but it covers all the quadrants in the last period. This thematic area covers themes related to BERNE-VIRUS, BETA-CORONAVIRUS, BOVINE-CORONAVIRUS, BREDA-VIRUS, CANINE-CORONAVIRUS, CORONAVIRUS-JHM, ENTERIC-CORONAVIRUS, FELINE-INFECTIOUS-PERITONITIS, HEPATITIS-C-VIRUS, HUMAN-CORONAVIRUS-NL63, HUMAN-METAPNEUMOVIRUS, INFECTIOUS-BRONCHITIS-VIRUS, INFLUENZA-VIRUS-TYPE-A, LELYSTAD-VIRUS, MOUSE-HEPATITIS-CORONAVIRUS, NIPAH-VIRUS, PORCINE-EPIDEMIC-DIARRHEA-VIRUS, RESPIRATORY-VIRUSES, SIALODACRYOADENITIS-VIRUS, SINDBIS-VIRUS, TRANSMISSIBLE-GASTROENTERITIS-CORONAVIRUS, TRANSMISSIBLE-GASTROENTERITIS-VIRUS, and WINTER-DYSENTERY.

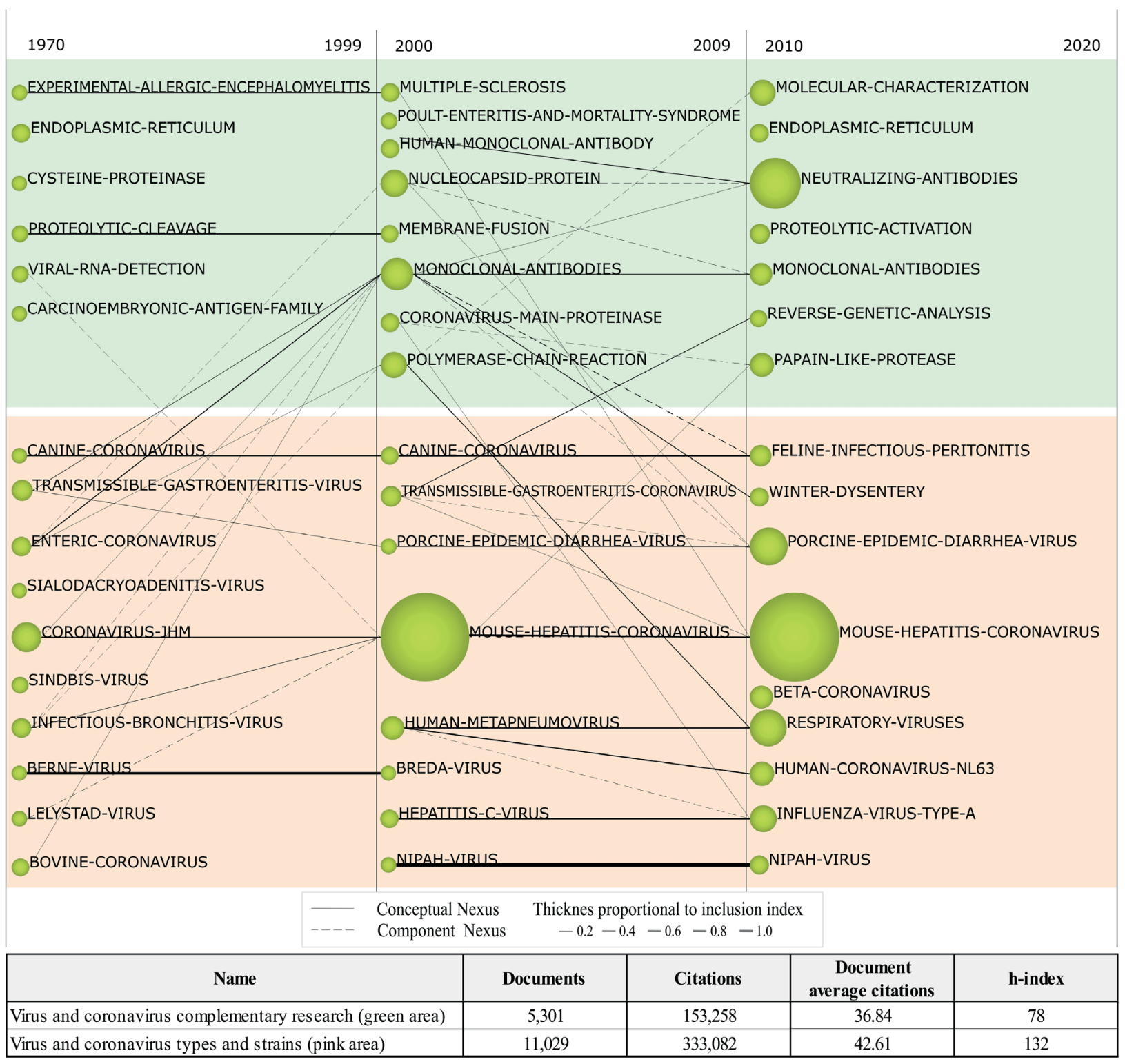

Figure 7. Evolution of thematic areas (1970-2020) 
Virus and coronavirus complementary research (green area) is the second thematic area within the map in terms of number of publications. It has 5,301 publications, 153,258 citations, and 78 highly cited publications according to the h-index. This thematic area contains the motor themes, highly developed and isolated themes, and emerging or declining themes in all the periods, but it covers all the quadrants in the last period. Regarding its thematic composition, this thematic area covers themes related to CARCINOEMBRYONIC-ANTIGEN-FAMILY, CORONAVIRUS-MAIN-PROTEINASE, CYSTEINE-PROTEINASE, ENDOPLASMIC-RETICULUM, EXPERIMENTAL-ALLERGIC-ENCEPHALOMYELITIS, HUMAN-MONOCLONAL-ANTIBODY, MEMBRANE-FUSION, MOLECULAR-CHARACTERIZATION, MONOCLONAL-ANTIBODIES, MULTIPLE-SCLEROSIS NEUTRALIZING-ANTIBODIES, NUCLEOCAPSID-PROTEIN, PAPAIN-LIKE-PROTEASE, POLYMERASE-CHAIN-REACTION, POULT-ENTERITIS-AND-MORTALITY-SYNDROME, PROTEOLYTIC-ACTIVATION, PROTEOLYTIC-CLEAVAGE, REVERSE-GENETIC-ANALYSIS, and VIRAL-RNA-DETECTION.

Therefore, it is important to emphasize that all the thematic areas include themes from the motor themes, highly developed and isolated themes, and basic and transversal themes and present a growing pattern in the last period. This growth can be considered to reflect the growing interest in coronavirus research within the scientific and business community.

However, according to the bibliometric methodology implemented by SciMAT as described herein, the evolution maps can be used to reveal the pattern of development within the field throughout the periods analyzed based on the interaction between the graphical elements. Therefore, the size of the spheres is proportional to the number of publications associated with each theme, while the colored areas represent the clusters of themes pertaining to the same thematic area. Moreover, the solid line represents the thematic link between the different areas, while the dotted line indicates that related thematic areas share some keywords. Furthermore, the thickness of the lines is proportional to the rate of inclusion (Cobo et al., 2012). The conceptual evolution and thematic areas identified are shown in Figure 7.

\section{Conclusions}

The current analysis represents the first bibliometric study on coronavirus types and strains since the first publication in 1970 to the present day, with an emphasis on Covid-19 disease and using SciMAT. It therefore focuses on an analysis and description of the development of the research themes about coronavirus and the main related concepts available in the literature using bibliometric techniques and tools. It establishes a holistic approach to identify new research that supports the interest of the scientific community.

In terms of bibliometric volume, more than 12,571 original research publications have been processed and analyzed. The size of this literature related to research on coronavirus, its main types and strains, and complementary themes has shown a noteworthy increase over the past 50 years (1970-2020). Given the large volume of publications and citations received and the current global disease, it is expected that such interest will continue to grow and serve as a support to different knowledge areas such as virology, veterinary sciences, biochemistry, molecular biology, immunology, infectious diseases, microbiology, biotechnology, applied microbiology, experimental medical research, pharmacology, pharmacy, and public, environmental, and occupational health, among others.

Accordingly, coronavirus research published during the period from 1970 to 2020 includes papers coauthored by 35,359 researchers from 462 organizations and 145 different countries. The publications analyzed have received more than 382,447 citations (including self-citations) according to Web of Science Core Collection. The most productive authors are Yuen, Perlman, Baric, Enjuanes, Weiss, Drosten, Rottier, Woo, Chan, Saif, Lau, and Snijder, and the most cited are Yuen, Chan, Drosten, Osterhaus, Peiris, Guan, Poon, Snijder, Woo, Rottier, and Enjuanes. The correspondence between the most productive and most cited authors reflects the balance and quality of the publications analyzed.

Moreover, the most productive countries are the USA, China, the UK, Germany, the Netherlands, Canada, Japan, France, South Korea, Italy, and Taiwan. Furthermore, the most productive organizations are University of Hong Kong, Chinese Academy of Sciences, University of California System, National Institutes of Health (USA), Utrecht University, University of North Carolina, Centers for Disease Control and Prevention (USA), University of Texas System, University of North Carolina Chapel Hill, University of Pennsylvania, and Chinese University of Hong Kong. As with the previous point, the most productive countries and most productive organizations reflect the position of the main agents in this field.

In this regard, the number of core publications related to coronavirus research identified by using the h-index and $\mathrm{H}$-classics is 192. In terms of citations, their citation distribution reveals a positive developmental trend, with a total of 72,763 citations (including self-citations) being recorded and the average number of citations per cited article being 378.97.

In addition, based on the results of the bibliometric analysis, this research provides a visual overview of the development and structure of the main types and strains of coronavirus and related themes over the past 50 years (1970-2020).

The intellectual structure of coronavirus research and its main themes described in the literature are arranged into two 
thematic areas: virus and coronavirus complementary research and virus and coronavirus types and strains. These thematic areas support a visualization of coronavirus types and strains, with its main components covering aspects from the identification and characterization of the virus to its evolution and solutions.

The research themes within these thematic areas that are considered to be key because of their contribution to the growth of the field are BOVINE-CORONAVIRUS, CORONAVIRUS-JHM, CORONAVIRUS-MAIN-PROTEINASE, ENDOPLASMIC-RETICULUM, ENTERIC-CORONAVIRUS, HUMAN-CORONAVIRUS-NL63, HUMAN-METAPNEUMOVIRUS, INFECTIOUS-BRONCHITIS-VIRUS, INFLUENZA-VIRUS-TYPE-A, LELYSTAD-VIRUS, MOLECULAR-CHARACTERIZATION, MONOCLONAL-ANTIBODIES, MOUSE-HEPATITIS-CORONAVIRUS, MULTIPLE-SCLEROSIS, NEUTRALIZING-ANTIBODIES, NUCLEOCAPSID-PROTEIN, PAPAIN-LIKE-PROTEASE, POLYMERASE-CHAIN-REACTION, PORCINE-EPIDEMIC-DIARRHEA-VIRUS, RESPIRATORY-VIRUSES, SINDBIS-VIRUS, and TRANSMISSIBLE-GASTROENTERITIS-VIRUS.

After analyzing these lines of research and their evolution, this study finds that the development of coronavirus research will mainly support the following areas: virology, veterinary sciences, biochemistry, molecular biology, immunology, infectious diseases, microbiology, biotechnology, applied microbiology, experimental medical research, pharmacology, pharmacy, general medicine, and public and environmental occupational health.

In addition, the present study identified the following themes that will attract interest from the scientific community in the future: human coronavirus, genetic analysis, neutralizing antibodies, molecular characterization, coronavirus main proteinase, proteolytic activation, social and economic effects of coronavirus disease, and new research methods in fields related to the coronavirus, among others.

Finally, future work is necessary to provide a more in-depth examination of coronavirus research considering a multidisciplinary approach.

\section{Annexes}

\section{Table A.1 H-Classics of coronavirus}

\begin{tabular}{|c|c|c|}
\hline Rank & Title (Year, First author) & Citations \\
\hline 1 & A novel coronavirus associated with severe acute respiratory syndrome (2003, Ksiazek, T. G.) & 1,932 \\
\hline 2 & Identification of a novel coronavirus in patients with severe acute respiratory syndrome (2003, Drosten, C.) & 1,826 \\
\hline 3 & Characterization of a novel coronavirus associated with severe acute respiratory syndrome (2003, Ksiazek, T. G.) & 1,510 \\
\hline 4 & Coronavirus as a possible cause of severe acute respiratory syndrome (2003, Lim, W.) & 1,482 \\
\hline 5 & Isolation of a novel coronavirus from a man with pneumonia in Saudi Arabia (2012, Osterhaus, A. D. M. E.) & 1,389 \\
\hline 6 & Community study of role of viral-infections in exacerbations of asthma in 9-11 year-old children (1995, Johnston, S. L.) & 1,337 \\
\hline 7 & The genome sequence of the SARS-associated coronavirus (2003, Marra, M. A.) & 1,303 \\
\hline 8 & Cloning of a human parvovirus by molecular screening of respiratory tract samples (2005, Tammi, M. T.) & 1,038 \\
\hline 9 & Angiotensin-converting enzyme 2 is a functional receptor for the SARS coronavirus $(2003, \mathrm{Li}, \mathrm{W}$. H.) & 1,034 \\
\hline 10 & Psychological stress and susceptibility to the common cold (1991, Tyrrell, D. A. J.) & 1,011 \\
\hline 11 & Isolation and characterization of viruses related to the SARS coronavirus from animals in Southern China (2003, Lim, W.) & 934 \\
\hline 12 & Bats are natural reservoirs of SARS-like coronaviruses (2005, Li, W. D.) & 890 \\
\hline 13 & $\begin{array}{l}\text { Clinical progression and viral load in a community outbreak of coronavirus-associated SARS pneumonia: a prospective } \\
\text { study (2003, Peiris, J. S. M.) }\end{array}$ & 875 \\
\hline 14 & Regulation and cellular roles of ubiquitin-specific deubiquitinating enzymes ( 2009 , Reyes-Turcu, F. E.) & 791 \\
\hline 15 & Identification of a new human coronavirus (2004, van der Hoek, L.) & 771 \\
\hline 16 & $\begin{array}{l}\text { Unique and conserved features of genome and proteome of SARS-coronavirus, an early split-off from the coronavirus } \\
\text { group } 2 \text { lineage (2003, Poon, L. L. M.) }\end{array}$ & 686 \\
\hline 17 & Identification of severe acute respiratory syndrome in Canada (2003, Brunham, R. C.) & 685 \\
\hline 18 & Bats: Important reservoir hosts of emerging viruses (2006, Calisher, C. H.) & 679 \\
\hline 19 & Severe acute respiratory syndrome coronavirus-like virus in Chinese horseshoe bats (2005, Chan, K. H.) & 666 \\
\hline 20 & $\begin{array}{l}\text { Characterization and complete genome sequence of a novel coronavirus, coronavirus HKU1, from patients with pneumo- } \\
\text { nia (2005, Peiris, J. S. M.) }\end{array}$ & 660 \\
\hline 21 & Structural bioinformatics and its impact to biomedical science (2004, Chou, K. C.) & 636 \\
\hline 22 & $\begin{array}{l}\text { Lelystad virus, the causative agent of porcine epidemic abortion and respiratory syndrome (pears), is related to ldv and } \\
\text { eav (1993, Meulenberg, J. J. M.) }\end{array}$ & 609 \\
\hline
\end{tabular}




\begin{tabular}{|c|c|c|}
\hline 23 & Transmission dynamics and control of severe acute respiratory syndrome (2003, Lipsitch, M.) & 584 \\
\hline 24 & Hospital outbreak of Middle East respiratory syndrome coronavirus (2013, Assiri, A.) & 566 \\
\hline 25 & The molecular biology of coronaviruses (1997, Lai, M. M. C.) & 551 \\
\hline 26 & $\begin{array}{l}\text { Human infections with the emerging avian influenza A H7N9 virus from wet market poultry: clinical analysis and charac- } \\
\text { terisation of viral genome }(2013 \text {, Chan, K. H.) }\end{array}$ & 550 \\
\hline 27 & $\begin{array}{l}\text { Isolation and direct characterization of resident microglial cells from the normal and inflamed central-nervous-system } \\
(1991, \text { Sedgwick, J. D.) }\end{array}$ & 536 \\
\hline 28 & Clinical features of patients infected with 2019 novel coronavirus in Wuhan, China (2020, Huang, C. L.) & 529 \\
\hline 29 & Newly discovered coronavirus as the primary cause of severe acute respiratory syndrome (2003, Lim, W.) & 504 \\
\hline 30 & Dipeptidyl peptidase 4 is a functional receptor for the emerging human coronavirus-EMC (2013, Osterhaus, A. D. M. E.) & 499 \\
\hline 31 & RNA recombination in animal and plant-viruses (1992, Lai, M. M. C.) & 497 \\
\hline 32 & Identification of a novel polyomavirus from patients with acute respiratory tract infections (2007, Gaynor, A. M.) & 496 \\
\hline 33 & Porcine reproductive and respiratory syndrome virus comparison: Divergent evolution on two continents (1999, Nelsen, C. J.) & 495 \\
\hline 34 & From carbohydrate leads to glycomimetic drugs (2009, Ernst, B.) & 486 \\
\hline 35 & Current concepts: The severe acute respiratory syndrome (2003, Osterhaus, A. D. M. E.) & 483 \\
\hline 36 & Coronavirus main proteinase (3CL(pro)) structure: Basis for design of anti-SARS drugs (2003, Ziebuhr, J.) & 477 \\
\hline 37 & Virus-encoded proteinases and proteolytic processing in the Nidovirales (2000, Snijder, E. J.) & 469 \\
\hline 38 & $\begin{array}{l}\text { Characterization of an efficient coronavirus ribosomal frameshifting signal - requirement for an RNA pseudoknot (1989, } \\
\text { Brierley, I.) }\end{array}$ & 469 \\
\hline 39 & Human aminopeptidase- $n$ is a receptor for human coronavirus-229e (1992, Yeager, C. L.) & 460 \\
\hline 40 & Structures and mechanisms of viral membrane fusion proteins: Multiple variations on a common theme (2008, White, J. M.) & 450 \\
\hline 41 & Aminopeptidase-n is a major receptor for the enteropathogenic coronavirus TGEV (1992, Delmas, B.) & 427 \\
\hline 42 & Viruses and bacteria in the etiology of the common cold (1998, Makela, M. J.) & 426 \\
\hline 43 & Lung pathology of fatal severe acute respiratory syndrome $(2003$, Lim, W.) & 418 \\
\hline 44 & Angiotensin-converting enzyme 2 protects from severe acute lung failure (2005, Slutsky, A. S.) & 405 \\
\hline 45 & $\begin{array}{l}\text { Autoimmunity to myelin oligodendrocyte glycoprotein in rats mimics the spectrum of multiple sclerosis pathology } \\
(1998 \text {, Storch, M. K.) }\end{array}$ & 398 \\
\hline 46 & Human bocavirus and acute wheezing in children (2007, Allander, T.) & 396 \\
\hline 47 & $\begin{array}{l}\text { An efficient method to make human monoclonal antibodies from memory B cells: potent neutralization of SARS corona- } \\
\text { virus (2004, Becker, S.) }\end{array}$ & 390 \\
\hline 48 & Mechanisms and enzymes involved in SARS coronavirus genome expression (2003, Rabenau, H.) & 389 \\
\hline 49 & Impacts of bioinformatics to medicinal chemistry (2015, Chou, K. C.) & 387 \\
\hline 50 & $\begin{array}{l}\text { The coronavirus spike protein is a class I virus fusion protein: Structural and functional characterization of the fusion core } \\
\text { complex (2003, Bosch, B. J.) }\end{array}$ & 387 \\
\hline 51 & $\begin{array}{l}\text { Epidemiological, demographic, and clinical characteristics of } 47 \text { cases of Middle East respiratory syndrome coronavirus } \\
\text { disease from Saudi Arabia: a descriptive study }(2013, \text { Assiri, A.) }\end{array}$ & 386 \\
\hline 52 & 2'-O methylation of the viral mRNA cap evades host restriction by IFIT family members (2010, Thiel, V.) & 380 \\
\hline 53 & Factors that make an infectious disease outbreak controllable (2004, Fraser, C.) & 378 \\
\hline 54 & Coronavirus avian infectious bronchitis virus (2007, Cavanagh, D.) & 376 \\
\hline 55 & $\begin{array}{l}\text { Genomic characterization of a newly discovered coronavirus associated with acute respiratory distress syndrome in } \\
\text { humans }(2012 \text {, Osterhaus, A. D. M. E.) }\end{array}$ & 372 \\
\hline 56 & Pseudo amino acid composition and its applications in bioinformatics, proteomics and system biology (2009, Chou, K. C.) & 365 \\
\hline 57 & Glycyrrhizin, an active component of liquorice roots, and replication of SARS-associated coronavirus (2003, Rabenau, H.) & 365 \\
\hline 58 & Nidovirales: Evolving the largest RNA virus genome (2006, Snijder, E. J.) & 358 \\
\hline 59 & Network theory and SARS: predicting outbreak diversity (2005, Brunham, R. C.) & 358 \\
\hline 60 & Severe acute respiratory syndrome (2004, Peiris, J. S. M.) & 358 \\
\hline 61 & $\begin{array}{l}\text { Middle East respiratory syndrome coronavirus neutralising serum antibodies in dromedary camels: a comparative serolo- } \\
\text { gical study (2013, Osterhaus, A. D. M. E.) }\end{array}$ & 353 \\
\hline 62 & $\begin{array}{l}\text { Contamination, disinfection, and cross-colonization: Are hospital surfaces reservoirs for nosocomial infection? (2004, } \\
\text { Hota, B.) }\end{array}$ & 351 \\
\hline 63 & Equine arteritis virus is not a togavirus but belongs to the coronaviruslike superfamily (1991, Denboon, J. A.) & 343 \\
\hline 64 & $\begin{array}{l}\text { Emergence of Porcine epidemic diarrhea virus in the United States: clinical signs, lesions, and viral genomic sequences } \\
(2013 \text {, Stevenson, G. W.) }\end{array}$ & 341 \\
\hline 65 & A previously undescribed coronavirus associated with respiratory disease in humans (2004, Fouchier, R. A. M.) & 340 \\
\hline
\end{tabular}




\begin{tabular}{|c|c|c|}
\hline 66 & $\begin{array}{l}\text { Discovery of seven novel mammalian and avian coronaviruses in the genus deltacoronavirus supports bat coronaviruses } \\
\text { as the gene source of alphacoronavirus and betacoronavirus and avian coronaviruses as the gene source of gammacoro- } \\
\text { navirus and deltacoronavirus }(2012, \text { Chan, } \mathrm{K} \text {. H.) }\end{array}$ & 339 \\
\hline 67 & $\begin{array}{l}\text { The crystal structures of severe acute respiratory syndrome virus main protease and its complex with an inhibitor (2003, } \\
\text { Anand, K.) }\end{array}$ & 338 \\
\hline 68 & $\begin{array}{l}\text { Porcine epidemic diarrhoea virus: a comprehensive review of molecular epidemiology, diagnosis, and vaccines (2012, } \\
\text { Song, D.) }\end{array}$ & 337 \\
\hline 69 & A novel coronavirus from patients with pneumonia in China, 2019 (2020, Li, X. W.) & 330 \\
\hline 70 & Structure of SARS coronavirus spike receptor-binding domain complexed with receptor (2005, Li, W. H.) & 329 \\
\hline 71 & $\begin{array}{l}\text { Binding mechanism of coronavirus main proteinase with ligands and its implication to drug design against SARS (2003, } \\
\text { Chou, K. C.) }\end{array}$ & 329 \\
\hline 72 & $\begin{array}{l}\text { Rhinovirus and respiratory syncytial virus in wheezing children requiring emergency care - IgE and eosinophil analyses } \\
(1999, \text { Rakes, C. P.) }\end{array}$ & 326 \\
\hline 73 & A DNA vaccine induces SARS coronavirus neutralization and protective immunity in mice $(2004$, Huang, $Y)$. & 325 \\
\hline 74 & $\begin{array}{l}\text { Ribose } 2^{\prime} \text {-O-methylation provides a molecular signature for the distinction of self and non-self mRNA dependent on the } \\
\text { RNA sensor Mda5 (2011, Thiel, V.) }\end{array}$ & 324 \\
\hline 75 & Isolation and characterization of a bat SARS-like coronavirus that uses the ACE2 receptor (2013, Ge, X. Y.) & 323 \\
\hline 76 & The molecular biology of coronaviruses (2006, Masters, P. S.) & 323 \\
\hline 77 & Emerging roles of cysteine cathepsins in disease and their potential as drug targets $(2007$, Vasiljeva, 0.$)$ & 319 \\
\hline 78 & Cross-species virus transmission and the emergence of new epidemic diseases (2008, Calisher, C. H.) & 313 \\
\hline 79 & Characterization of proteins encoded by orf- 2 to orf-7 of lelystad-virus (1995, Meulenberg, J. J. M.) & 312 \\
\hline 80 & Viral discovery and sequence recovery using DNA microarrays (2003, Ksiazek, T. G.) & 308 \\
\hline 81 & Evidence for camel-to-human transmission of MERS coronavirus (2014, Azhar, E. I.) & 307 \\
\hline 82 & Inhibitors of cathepsin L prevent severe acute respiratory syndrome coronavirus entry $(2005$, Simmons, G.) & 306 \\
\hline 83 & Completion of the sequence of the genome of the coronavirus avian infectious-bronchitis virus (1987, Boursnell, M. E. G.) & 306 \\
\hline 84 & $\begin{array}{l}\text { SARS-coronavirus replication is supported by a reticulovesicular network of modified endoplasmic reticulum (2008, } \\
\text { Snijder, E. J.) }\end{array}$ & 305 \\
\hline 85 & $\begin{array}{l}\text { Epidemiological and clinical characteristics of } 99 \text { cases of } 2019 \text { novel coronavirus pneumonia in Wuhan, China: a descrip- } \\
\text { tive study (2020, Zhang, L.) }\end{array}$ & 304 \\
\hline 86 & Epidemic dynamics at the human-animal interface (2009, Lloyd-Smith, J. O.) & 298 \\
\hline 87 & Coronaviruses post-SARS: update on replication and pathogenesis (2009, Perlman, S.) & 297 \\
\hline 88 & Middle East respiratory syndrome coronavirus in dromedary camels: an outbreak investigation (2014, Osterhaus, A. D. M. E.) & 295 \\
\hline 89 & Using siRNA in prophylactic and therapeutic regimens against SARS coronavirus in rhesus macaque (2005, Zheng, B. J.) & 295 \\
\hline 90 & Rhinovirus-induced wheezing in infancy-the first sign of childhood asthma? (2003, Kotaniemi-Syrjanen, A.) & 294 \\
\hline 91 & Predicting linear B-cell epitopes using string kernels (2008, El-Manzalawy, Y.) & 293 \\
\hline 92 & A crucial role of angiotensin converting enzyme 2 (ACE2) in SARS coronavirus-induced lung injury $(2005$, Slutsky, A. S.) & 293 \\
\hline 93 & $\begin{array}{l}\text { The complete sequence ( } 22 \text { kilobases) of murine coronavirus gene-1 encoding the putative proteases and rna-polymera- } \\
\text { se (1991, Lai, M. M. C.) }\end{array}$ & 293 \\
\hline 94 & $\begin{array}{l}\text { A } 193 \text {-amino acid fragment of the SARS coronavirus S protein efficiently binds angiotensin-converting enzyme } 2 \text { (2004, } \\
\text { Li, W. H.) }\end{array}$ & 289 \\
\hline 95 & Molecular evolution of the SARS coronavirus during the course of the SARS epidemic in China (2004, Hu, Z. H.) & 288 \\
\hline 96 & $\begin{array}{l}\text { Tissue distribution of ACE2 protein, the functional receptor for SARS coronavirus. A first step in understanding SARS } \\
\text { pathogenesis (2004, Hamming, I.) }\end{array}$ & 287 \\
\hline 97 & Middle East respiratory syndrome coronavirus in bats, Saudi Arabia (2013, Memish, Z. A.) & 286 \\
\hline 98 & $\begin{array}{l}\text { Receptor for mouse hepatitis-virus is a member of the carcinoembryonic antigen family of glycoproteins (1991, Williams, } \\
\text { R. K.) }\end{array}$ & 281 \\
\hline 99 & $\begin{array}{l}\text { Cloning of the mouse hepatitis-virus (MHV) receptor - expression in human and hamster-cell lines confers susceptibility } \\
\text { to MHV (1991, Williams, R. K.) }\end{array}$ & 275 \\
\hline 100 & SARS virus infection of cats and ferrets (2003, Lim, W.) & 273 \\
\hline 101 & $\begin{array}{l}\text { Nucleocapsid-independent assembly of coronavirus-like particles by co-expression of viral envelope protein genes (1996, } \\
\text { Rottier, P. J. M.) }\end{array}$ & 273 \\
\hline 102 & $\begin{array}{l}\text { Potent neutralization of severe acute respiratory syndrome (SARS) coronavirus by a human mAb to S1 protein that blocks } \\
\text { receptor association ( } 2004 \text {, Bellini, W. J.) }\end{array}$ & 272 \\
\hline 103 & $\begin{array}{l}\text { Comparative full-length genome sequence analysis of } 14 \text { SARS coronavirus isolates and common mutations associated } \\
\text { with putative origins of infection }(2003, \text { Ruan, Y. J.) }\end{array}$ & 272 \\
\hline 104 & Virus glycosylation: role in virulence and immune interactions (2007, Vigerust, D. J.) & 271 \\
\hline
\end{tabular}




\begin{tabular}{|c|c|c|}
\hline 105 & $\begin{array}{l}\text { Putative papain-related thiol proteases of positive-strand RNA viruses - identification of rubivirus and aphthovirus } \\
\text { proteases and delineation of a novel conserved domain associated with proteases of rubivirus, alpha- and coronaviruses } \\
(1991, \text { Lai, M. M. C.) }\end{array}$ & 268 \\
\hline 106 & Zoonoses 3 prediction and prevention of the next pandemic zoonosis (2012, Daszak, P.) & 266 \\
\hline 107 & Pathogenicity of antigenic variants of murine coronavirus JHM selected with monoclonal-antibodies (1986, Fleming, J. O.) & 266 \\
\hline 108 & Cross-host evolution of severe acute respiratory syndrome coronavirus in palm civet and human (2005, Tong, S. X.) & 264 \\
\hline 109 & Coronavirus spike proteins in viral entry and pathogenesis (2001, Gallagher, T. M.) & 264 \\
\hline 110 & Incubation periods of acute respiratory viral infections: a systematic review (2009, Perl, T. M.) & 262 \\
\hline 111 & RNA replication of mouse hepatitis virus takes place at double-membrane vesicles (2002, Gosert, R.) & 261 \\
\hline 112 & $\begin{array}{l}\text { Clinical characteristics of } 138 \text { hospitalized patients with } 2019 \text { novel coronavirus-infected pneumonia in Wuhan, China } \\
(2020, \text { Cheng, Z. S.) }\end{array}$ & 260 \\
\hline 113 & Database resources of the National Center for Biotechnology Information: update (2004, Wheeler, D. L.) & 260 \\
\hline 114 & $\begin{array}{l}\text { Epidemiology and cause of severe acute respiratory syndrome (SARS) in Guangdong, People's Republic of China, in } \\
\text { February, } 2003 \text { ( } 2003, \text { Peiris, J. S. M.) }\end{array}$ & 255 \\
\hline 115 & $\begin{array}{l}\text { Origin, evolution, and genotyping of emergent porcine epidemic diarrhea virus strains in the United States (2013, Huang, } \\
\text { Y.W.) }\end{array}$ & 252 \\
\hline 116 & Evidence of human coronavirus HKU1 and human bocavirus in Australian children (2006, Sloots, T. P.) & 252 \\
\hline 117 & Coronavirus-organization, replication and expression of genome (1990, Lai, M. M. C.) & 252 \\
\hline 118 & $\begin{array}{l}\text { The association of newly identified respiratory viruses with lower respiratory tract infections in Korean children, 2000- } \\
2005(2006, \text { Choi, E. H.) }\end{array}$ & 251 \\
\hline 119 & Virus maturation by budding (1998, Opstelten, D. J. E.) & 251 \\
\hline 120 & Coronavirus pathogenesis and the emerging pathogen severe acute respiratory syndrome coronavirus $(2005$, Weiss, S. R.) & 250 \\
\hline 121 & $\begin{array}{l}\text { Development of a respiratory virus panel test for detection of twenty human respiratory viruses by use of multiplex PCR } \\
\text { and a fluid microbead-based assay }(2007, \text { Mahony, J.) }\end{array}$ & 247 \\
\hline 122 & Middle East respiratory syndrome (2015, Perlman, S.) & 246 \\
\hline 123 & Transmission of the severe acute respiratory syndrome on aircraft (2003, Dowell, S. F.) & 245 \\
\hline 124 & $\begin{array}{l}\text { Orderly order in protein intrinsic disorder distribution: disorder in } 3500 \text { proteomes from viruses and the three domains of } \\
\text { life }(2012, \text { Xue, B.) }\end{array}$ & 244 \\
\hline 125 & Distinct patterns of IFITM-mediated restriction of filoviruses, SARS coronavirus, and influenza A virus (2011, Huang, I. C.) & 244 \\
\hline 126 & Autophagy: Principles and significance in health and disease (2009, Todde, V.) & 244 \\
\hline 127 & Detection of respiratory viruses by molecular methods (2008, Mahony, J. B.) & 244 \\
\hline 128 & Transferrin receptor 1 is a cellular receptor for New World haemorrhagic fever arenaviruses (2007, Radoshitzky, S. R.) & 244 \\
\hline 129 & Molecular basis of binding between novel human coronavirus MERS-CoV and its receptor CD26 (2013, Zhang, W.) & 240 \\
\hline 130 & Induction of incomplete autophagic response by hepatitis C virus via the unfolded protein response (2008, Sir, D.) & 240 \\
\hline 131 & Isolation of coronavirus envelope glycoproteins and interaction with the viral nucleocapsid (1980, Holmes, K. V.) & 239 \\
\hline 132 & A pneumonia outbreak associated with a new coronavirus of probable bat origin (2020, Yang, X. L.) & 236 \\
\hline 133 & A pneumonia outbreak associated with a new coronavirus of probable bat origin (2020, Yang, X. L.) & 236 \\
\hline 134 & An efficient ribosomal frame-shifting signal in the polymerase-encoding region of the coronavirus IBV (1987, Brierley, I.) & 236 \\
\hline 135 & $\begin{array}{l}\text { Clinical features and viral diagnosis of two cases of infection with Middle East Respiratory Syndrome coronavirus: a report } \\
\text { of nosocomial transmission (2013, Guery, B.) }\end{array}$ & 235 \\
\hline 136 & Family cluster of Middle East respiratory syndrome coronavirus infections (2013, Zumla, A. I.) & 234 \\
\hline 137 & $\begin{array}{l}\text { Severe acute respiratory syndrome coronavirus spike protein expressed by attenuated vaccinia virus protectively immu- } \\
\text { nizes mice }(2004 \text {, Subbarao, K.) }\end{array}$ & 233 \\
\hline 138 & $\begin{array}{l}\text { Clinical features and complete genome characterization of a distinct human rhinovirus (HRV) genetic previously unde- } \\
\text { tected HRV cluster, probably representing a species, HRV-C, associated with acute respiratory illness in children (2007, } \\
\text { Chan, K. H.) }\end{array}$ & 232 \\
\hline 139 & $\begin{array}{l}\text { Ovarian tumor domain-containing viral proteases evade ubiquitin- and ISG15-dependent innate immune responses } \\
(2007 \text {, Snijder, E. J.) }\end{array}$ & 231 \\
\hline 140 & Coronavirus replication complex formation utilizes components of cellular autophagy (2004, Prentice, E.) & 230 \\
\hline 141 & $\begin{array}{l}\text { Prior infection and passive transfer of neutralizing antibody prevent replication of severe acute respiratory syndrome } \\
\text { coronavirus in the respiratory tract of mice }(2004 \text {, Shieh, W. J.) }\end{array}$ & 229 \\
\hline 142 & $\begin{array}{l}\text { Retargeting of coronavirus by substitution of the spike glycoprotein ectodomain: Crossing the host cell species barrier } \\
(2000 \text {, Rottier, P. J. M.) }\end{array}$ & 229 \\
\hline 143 & 2014 MERS-CoV outbreak in Jeddah - A link to health care facilities (2015, Madani, T. A.) & 228 \\
\hline 144 & $\begin{array}{l}\text { Severe respiratory illness caused by a novel coronavirus, in a patient transferred to the United Kingdom from the Middle } \\
\text { East, September } 2012 \text { (2012, Bermingham, A. ) }\end{array}$ & 228 \\
\hline 145 & Autophagosome supports coxsackievirus B3 replication in host cells (2008, Wong, J.) & 228 \\
\hline
\end{tabular}




\begin{tabular}{|c|c|c|}
\hline 146 & Receptor and viral determinants of SARS-coronavirus adaptation to human ACE2 (2005, Guan, Y.) & 227 \\
\hline 147 & Development of three multiplex RT-PCR assays for the detection of 12 respiratory RNA viruses (2005, Bellau-Pujol, S.) & 225 \\
\hline 148 & $\begin{array}{l}\text { Coronavirus genome - prediction of putative functional domains in the non-structural polyprotein by comparative ami- } \\
\text { no-acid sequence-analysis }(1989, \text { Gorbalenya, A. E.) }\end{array}$ & 223 \\
\hline 149 & $\begin{array}{l}\text { Coronavirus transcription - subgenomic mouse hepatitis-virus replicative intermediates function in rna-synthesis (1990, } \\
\text { Sawicki, S. G.) }\end{array}$ & 222 \\
\hline 150 & $\begin{array}{l}\text { Severe acute respiratory syndrome coronavirus open reading frame (ORF) 3b, ORF } 6 \text {, and nucleocapsid proteins function } \\
\text { as interferon antagonists (2007, Kopecky-Bromberg, S. A.) }\end{array}$ & 221 \\
\hline 151 & $\begin{array}{l}\text { Lambda interferon renders epithelial cells of the respiratory and gastrointestinal tracts resistant to viral infections (2010, } \\
\text { Drosten, C.) }\end{array}$ & 220 \\
\hline 152 & $\begin{array}{l}\text { Characterization of severe acute respiratory syndrome-associated coronavirus (SARS-CoV) spike glycoprotein-mediated } \\
\text { viral entry (2004, Simmons, G.) }\end{array}$ & 220 \\
\hline 153 & Feline infectious peritonitis viruses arise by mutation from endemic feline enteric coronaviruses (1998, Vennema, H.) & 220 \\
\hline 154 & $\begin{array}{l}\text { Heptad repeat sequences are located adjacent to hydrophobic regions in several types of virus fusion glycoproteins } \\
(1990, \text { Chambers, } P .)\end{array}$ & 220 \\
\hline 155 & Wildlife trade and global disease emergence (2005, Karesh, W. B.) & 218 \\
\hline 156 & CD209L (L-SIGN) is a receptor for severe acute respiratory syndrome coronavirus (2004, Jeffers, S. A.) & 217 \\
\hline 157 & $\begin{array}{l}\text { Simultaneous detection of fourteen respiratory viruses in clinical specimens by two multiplex reverse transcription } \\
\text { nested-PCR assays ( } 2004 \text {, Coiras, M. T.) }\end{array}$ & 217 \\
\hline 158 & $\begin{array}{l}\text { Proteolytic cleavage of the e2-glycoprotein of murine coronavirus - activation of cell-fusing activity of virions by trypsin } \\
\text { and separation of } 2 \text { different } 90 \text { k-cleavage fragments }(1985, \text { Holmes, K. V.) }\end{array}$ & 217 \\
\hline 159 & Panmicrobial oligonucleotide array for diagnosis of infectious diseases (2007, Briese, T.) & 216 \\
\hline 160 & Engineering the largest RNA virus genome as an infectious bacterial artificial chromosome (2000, Enjuanes, L.) & 215 \\
\hline 161 & $\begin{array}{l}\text { A familial cluster of pneumonia associated with the } 2019 \text { novel coronavirus indicating person-to-person transmission: a } \\
\text { study of a family cluster }(2020, \text { Chan, K. H.) }\end{array}$ & 214 \\
\hline 162 & $\begin{array}{l}\text { Delayed antiviral plus immunomodulator treatment still reduces mortality in mice infected by high inoculum of influenza } \\
\text { A/H5N1 virus }(2008, \text { Chan, K. H.) }\end{array}$ & 214 \\
\hline 163 & Real-time reverse transcription PCR (qRT-PCR) and its potential use in clinical diagnosis (2005, Bustin, S. A.) & 214 \\
\hline 164 & Autophagic machinery activated by dengue virus enhances virus replication (2008, Lee, Y. R.) & 213 \\
\hline 165 & $\begin{array}{l}\text { pH-dependent entry of Severe acute respiratory syndrome coronavirus is mediated by the spike glycoprotein and enhan- } \\
\text { ced by dendritic cell transfer through DC-SIGN (2004, Huang, Y.) }\end{array}$ & 213 \\
\hline 166 & $\begin{array}{l}\text { Feline coronavirus type II strains } 79-1683 \text { and } 79-1146 \text { originate from a double recombination between feline coronavirus } \\
\text { type I and canine coronavirus }(1998, \text { Rottier, P. J. M.) }\end{array}$ & 213 \\
\hline 167 & Antivirals and antiviral strategies (2004, De Clercq, E.) & 212 \\
\hline 168 & Early transmission dynamics in Wuhan, China, of novel coronavirus-infected pneumonia (2020, Yang, B.) & 211 \\
\hline 169 & $\begin{array}{l}\text { Development and evaluation of a novel loop-mediated isothermal amplification method for rapid detection of severe } \\
\text { acute respiratory syndrome coronavirus (2004, Thai, H. T. C.) }\end{array}$ & 210 \\
\hline 170 & $\begin{array}{l}\text { Interaction between heptad repeat } 1 \text { and } 2 \text { regions in spike protein of SARS-associated coronavirus: implications for virus } \\
\text { fusogenic mechanism and identification of fusion inhibitors (2004, Liu, S. W.) }\end{array}$ & 210 \\
\hline 171 & $\begin{array}{l}\text { Structure of coronavirus main proteinase reveals combination of a chymotrypsin fold with an extra alpha-helical domain } \\
(2002, \text { Ziebuhr, J.) }\end{array}$ & 210 \\
\hline 172 & Mannose-binding lectin in innate immunity: past, present and future (2006, Dommett, R. M.) & 209 \\
\hline 173 & Plasma inflammatory cytokines and chemokines in severe acute respiratory syndrome (2004, Wong, C. K.) & 209 \\
\hline 174 & Frequency and natural history of rhinovirus infections in adults during autumn (1997, Arruda, E.) & 209 \\
\hline 175 & Reverse genetics with a full-length infectious cDNA of severe acute respiratory syndrome coronavirus $(2003$, Prentice, E.) & 208 \\
\hline 176 & $\begin{array}{l}\text { Establishment of B-cell lymphoma cell lines persistently infected with hepatitis C virus in vivo and in vitro: the apototic } \\
\text { effects of virus infection (2003, Lai, M. M. C.) }\end{array}$ & 204 \\
\hline 177 & Clinical features and virological analysis of a case of Middle East respiratory syndrome coronavirus infection $(2013$, Muth, D.) & 203 \\
\hline 178 & $\begin{array}{l}\text { Pegylated interferon-alpha protects type } 1 \text { pneumocytes against SARS coronavirus infection in macaques (2004, Fou- } \\
\text { chier, R. A. M.) }\end{array}$ & 200 \\
\hline 179 & Human bocavirus: Passenger or pathogen in acute respiratory tract infections? (2008, Mackay, I. M.) & 199 \\
\hline 180 & Viral upper respiratory tract infection and otitis media complication in young children $(2008$, Chonmaitree, T.) & 199 \\
\hline 181 & Persistence of rhinovirus and enterovirus RNA after acute respiratory illness in children $(2004$, Ruuskanen, 0.$)$ & 199 \\
\hline 182 & Cytoplasmic viral replication complexes (2010, den Boon, J. A.) & 198 \\
\hline 183 & $\begin{array}{l}\text { Adoptive transfer of eae-like lesions from rats with coronavirus-induced demyelinating encephalomyelitis (1983, Termeu- } \\
\text { len, V.) }\end{array}$ & 197 \\
\hline 184 & The papain-like protease of severe acute respiratory syndrome coronavirus has deubiquitinating activity $(2005$, Baker, S. C.) & 196 \\
\hline
\end{tabular}




\begin{tabular}{|c|l|c|}
\hline 185 & Coronaviruses in poultry and other birds (2005, Cavanagh, D.) & 196 \\
\hline 186 & Systematic assembly of a full-length infectious cDNA of mouse hepatitis virus strain A59 (2002, Weiss, S. R.) & 196 \\
\hline 187 & $\begin{array}{l}\text { The genome organization of the nidovirales: Similarities and differences between arteri-, toro-, and coronaviruses (1997, } \\
\text { Rottier, P. J. M.) }\end{array}$ & 196 \\
\hline 188 & Impaired heart contractility in apelin gene-deficient mice associated with aging and pressure overload (2007, Kuba, K.) & 195 \\
\hline 189 & Nidovirus transcription: how to make sense...? (2006, Snijder, E. J.) & 195 \\
\hline 190 & Identification of a novel coronavirus in bats (2005, Peiris, J. S. M.) & 195 \\
\hline 191 & An enteric coronavirus infection of cats and its relationship to feline infectious peritonitis (1981, Pedersen, N. C.) & 195 \\
\hline 192 & $\begin{array}{l}\text { Pan-viral screening of respiratory tract infections in adults with and without asthma reveals unexpected human coronavi- } \\
\text { rus and human rhinovirus diversity (2007, Wang, D.) }\end{array}$ & 193 \\
\hline
\end{tabular}

\section{References}

Bonilla-Aldana, D. Katterine; Quintero-Rada, Keidenis; Montoya-Posada, Juan Pablo; Ramírez-Ocampo, Sebastián; Paniz-Mondolfi, Alberto; Rabaan, Ali A.; Sah, Ranjit; Rodríguez-Morales, Alfonso J. (2020). "SARS-CoV, MERS-CoV and now the 2019-novel CoV: Have we investigated enough about coronaviruses?-A bibliometric analysis". Travel medicine and infectious disease, v. 33, 101566.

https://doi.org/10.1016/j.tmaid.2020.101566

Callon, Michael; Courtial, Jean-Pierre; Turner, William A.; Bauin, Serge (1983). "From translations to problematic networks: An introduction to co-word analysis". Information (International Social Science Council), v. 22, n. 2, pp. $191-235$. https://doi.org/10.1177/053901883022002003

Callon, Michael; Courtial, Jean Pierre; Laville, Francoise (1991). "Co-word analysis as a tool for describing the network of interactions between basic and technological research: The case of polymer chemsitry". Scientometrics, v. 22, n. 1, pp. 155-205.

https://doi.org/10.1007/BF02019280

Casero-Ripollés, Andreu (2020). "Impact of Covid-19 on the media system. Communicative and democratic consequences of news consumption during the outbreak". El profesional de la información, v. 29, n. 2, e290223.

https://doi.org/10.3145/epi.2020.mar.23

Cobo, Manuel-Jesús; López-Herrera, Antonio-Gabriel; Herrera-Viedma, Enrique; Herrera, Francisco (2011). “An approach for detecting, quantifying, and visualizing the evolution of a research field: A practical application to the Fuzzy Sets Theory field". Journal of informetrics, v. 5, n. 1, pp. 146-166.

https://doi.org/10.1016/j.joi.2010.10.002

Cobo, Manuel-Jesús; López-Herrera, Antonio-Gabriel; Herrera-Viedma, Enrique; Herrera, Francisco (2012). "SciMAT: A new science mapping analysis software tool". Journal of the American Society for Information Science and Technology, v. 63, n. 8 , pp. $1609-1630$.

https://doi.org/10.1002/asi.22688

Coulter, Neal; Monarch, Ira; Konda, Suresh (1998). "Software engineering as seen through its research literature: A study in co-word analysis". Journal of the American Society for Information Science, v. 49, n. 13, pp. 1206-1223.

https://doi.org/10.1002/(SICI)1097-4571(1998)49:13\%3C1206::AID-ASI7\%3E3.0.CO;2-F

Garfield, Eugene (1986). "Towards Scientography”. Current comments, n. 43, pp. 324-335.

http://www.garfield.library.upenn.edu/essays/v9p324y1986.pdf

Garfield, Eugene; Merton, Robert K. (1979). “Citation indexing: Its theory and application in science, technology, and humanities". New York: Wiley. ISBN: 9780471025597

He, Qin (1999). “Knowledge discovery through co-word analysis”. Library trends, v. 48, n. 1, pp. 133-159.

https://www.ideals.illinois.edu/bitstream/handle/2142/8267/librarytrendsv48i1i_opt.pdf

Hirsch, Jorge E. (2005). "An index to quantify an individual's scientific research output". Proceedings of the National academy of Sciences, v. 102, n. 46, pp. 16569-16572.

https://doi.org/10.1073/pnas.0507655102

Hossain, Md-Mahbub (2020). "Current status of global research on novel coronavirus disease (Covid-19): A bibliometric analysis and knowledge mapping". F1000 Research.

https://doi.org/10.2139/ssrn.3547824

Lázaro-Rodríguez, Pedro; Herrera-Viedma, Enrique (2020). "Noticias sobre Covid-19 y 2019-nCoV en medios de comunicación de España: el papel de los medios digitales en tiempos de confinamiento". El profesional de la información, v. 29, n. 3, e290302.

https://doi.org/10.3145/epi.2020.may.02 
López-Robles, José-Ricardo; Guallar, Javier; Otegi-Olaso, José-Ramón; Gamboa-Rosales, Nadia-Karina (2019a). “El profesional de la información (EPI): bibliometric and thematic analysis (2006-2017)". El profesional de la información, v. 28, n. 4, e280417.

https://doi.org/10.3145/epi.2019.jul.17

López-Robles, José-Ricardo; Otegi-Olaso, Jose-Ramón; Porto-Gómez, Igone; Cobo, Manuel-Jesús (2019b). “30 years of intelligence models in management and business: A bibliometric review". International journal of information management, v. 48, pp. 22-38.

https://doi.org/10.1016/j.ijinfomgt.2019.01.013

López-Robles, José-Ricardo; Otegi-Olaso, José-Ramón; Porto-Gómez, Igone; Gamboa-Rosales, Hamurabi; Gamboa-Rosales, Nadia-Karina (2020). "Understanding the intellectual structure and evolution of competitive intelligence: A bibliometric analysis from 1984 to 2017". Technology analysis \& strategic management, v. 32, n. 5, pp. 604-619.

https://doi.org/10.1080/09537325.2019.1686136

Martínez, Miguel-Ángel; Cobo, Manuel-Jesús; Herrera, Manuel; Herrera-Viedma, Enrique (2015). “Analyzing the scientific evolution of social work using science mapping". Research on social work practice, v. 25, n. 2, pp. 257-277.

https://doi.org/10.1177/1049731514522101

Martínez, Miguel-Ángel; Herrera, Manuel; López-Gijón, Javier; Herrera-Viedma, Enrique (2014). “H-Classics: Characterizing the concept of citation classics through H-index". Scientometrics, v. 98, n. 3, pp. 1971-1983.

https://doi.org/10.1007/s11192-013-1155-9

Moed, Henk F. (2009). "New developments in the use of citation analysis in research evaluation". Archivum immunologiae et therapiae experimentalis, v. 57, 13.

https://doi.org/10.1007/s00005-009-0001-5

Moed, Henk F.; De-Bruin, R. E.; Van-Leeuwen, Thed (1995). "New bibliometric tools for the assessment of national research performance: Database description, overview of indicators and first applications". Scientometrics, v. 33, n. 3, pp. 381-422.

https://doi.org/10.1007/BF02017338

Moral-Muñoz, José A; Herrera-Viedma, Enrique; Santisteban-Espejo, Antonio; Cobo, Manuel-Jesús (2020). "Software tools for conducting bibliometric analysis in science: An up-to-date review". El profesional de la información v. 29, n. 1, e290103.

https://doi.org/10.3145/epi.2020.ene.03

Pérez-Dasilva, Jesús-Ángel; Meso-Ayerdi, Koldobika; Mendiguren-Galdospín, Terese (2020). “Fake news y coronavirus: detección de los principales actores y tendencias a través del análisis de las conversaciones en Twitter". El profesional de la información, v. 29, n. 3, e290308.

https://doi.org/10.3145/epi.2020.may.08

Rodríguez-Morales, Alfonso J.; Cardona-Ospina, Jaime A.; Gutiérrez-Ocampo, Estefanía; Villamizar-Peña, Rhuvi; Holguin-Rivera, Yeimer; Escalera-Antezana, Juan-Pablo; Alvarado-Arnez, Lucia-Elena; Bonilla-Aldana, D. Katterine; Franco-Paredes, Carlos; Henao-Martínez, Andrés F. (2020). "Clinical, laboratory and imaging features of Covid-19: A systematic review and meta-analysis". Travel medicine and infectious disease, v. 34, 101623.

https://doi.org/10.1016/j.tmaid.2020.101623

Sahin, Ahmet-Riza; Erdogan, Aysegul; Agaoglu, Pelin-Mutlu; Dineri, Yeliz; Cakirci, Ahmet-Yusuf; Senel, Mahmut-Egemen; Okyay, Ramazan-Azim; Tasdogan, Ali-Muhittin (2020). "2019 novel coronavirus (Covid-19) outbreak: a review of the current literature". EJMO, v. 4, n. 1, pp. 1-7.

https://dx.doi.org/10.14744/ejmo.2020.12220

Thelwall, Mike; Thelwall, Saheeda (2020). "Covid-19 tweeting in English: Gender differences". El profesional de la información, v. 29, n. 3, e290301.

https://doi.org/10.3145/epi.2020.may.01

Torres-Salinas, Daniel (2020). “Ritmo de crecimiento diario de la producción científica sobre Covid-19. Análisis en bases de datos y repositorios en acceso abierto". El profesional de la información, v. 29, n. 2, e290215.

https://doi.org/10.3145/epi.2020.mar.15

Wang, Jian (2013). "Citation time window choice for research impact evaluation”. Scientometrics, v. 94, n. 3, pp. $851-872$. https://doi.org/10.1007/s11192-012-0775-9

WHO (2020). “Coronavirus disease 2019 (Covid-19)". WHO Situation report. World Health Organization, n. 72.

https://apps.who.int/iris/bitstream/handle/10665/331685/nCoVsitrep01Apr2020-eng.pdf 